Discussion Papers

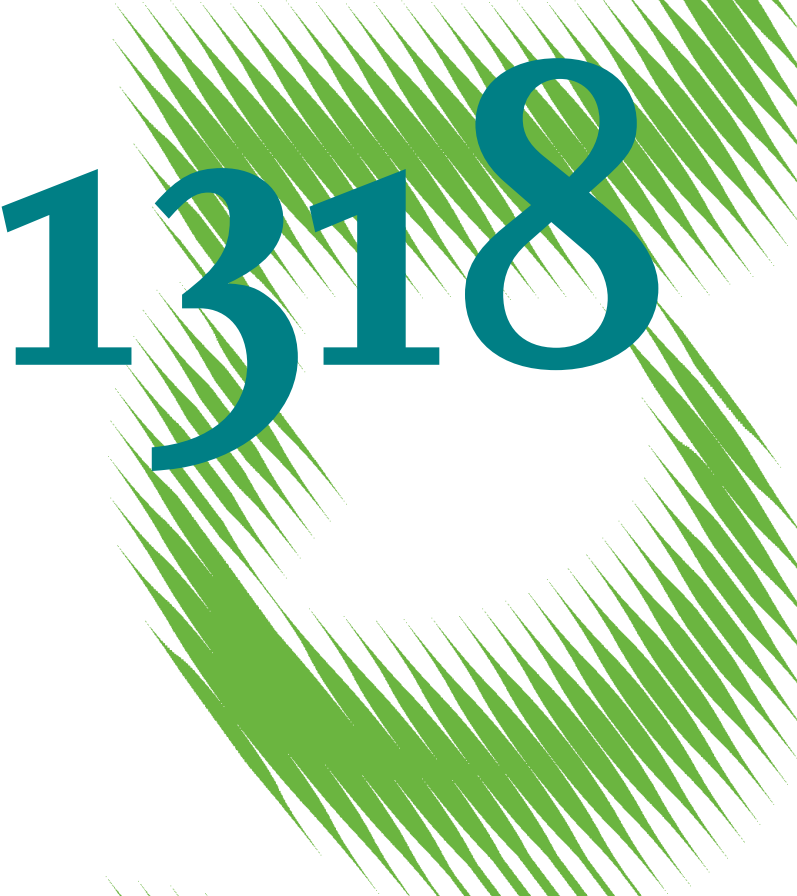

Impact of Renewable Energy Policy and Use on Innovation

A Literature Review 
Opinions expressed in this paper are those of the author(s) and do not necessarily reflect views of the institute.

IMPRESSUM

(C) DIW Berlin, 2013

DIW Berlin

German Institute for Economic Research

Mohrenstr. 58

10117 Berlin

Tel. $+49(30) 89789-0$

Fax +49 (30) $89789-200$

http://www.diw.de

ISSN print edition $1433-0210$

ISSN electronic edition 1619-4535

Papers can be downloaded free of charge from the DIW Berlin website:

http://www.diw.de/discussionpapers

Discussion Papers of DIW Berlin are indexed in RePEc and SSRN:

http://ideas.repec.org/s/diw/diwwpp.html

http://www.ssrn.com/link/DIW-Berlin-German-Inst-Econ-Res.html 
Wirkungen des Ausbaus Erneuerbarer Energien

- Impact of Renewable Energy Sources -

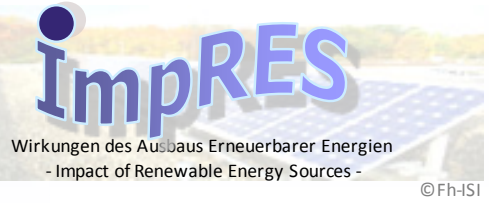

Supported by the German Federal Ministry for the Environment, Nature Conservation and Nuclear Safety (BMU)

\title{
Impact of renewable energy policy and use on innovation - a literature review
}

\author{
Felix Groba \\ German Institute of Economic Research (DIW Berlin), Berlin \\ Barbara Breitschopf \\ Fraunhofer Institute for Systems and Innovation Research (ISI), Karlsruhe
}

Berlin, Karlsruhe, July 2013

Corrected Version November 2013

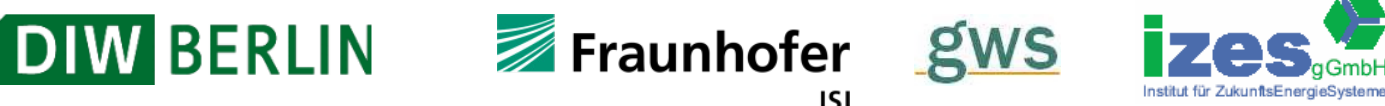




\begin{abstract}
:
Technological changes in renewable energy technologies play an important role in the context of climate change as they contribute to a reduction of technology costs and lead to an increasing market penetration of emission reducing technologies. This paper provides a comprehensive literature review highlighting numerous motivations and necessities underlying the introduction of renewable energy policies. Starting with a brief overview on the induced innovation hypothesis, we show that policy intervention has been an effective tool to change relative prices, thus, incentivizing innovation, but that also various influencing factors are at play. We show that the literature agrees on the need for specific renewable energy policies in order to overcome concomitant market failures and barrier. We highlight that technology specific policies are generally understood as necessary complements to environmental non-technology specific policies in order to generate adequate demand in energy markets. However, in that respect, we outline the ongoing debate on the effectiveness of different technology specific policies on the demand-pull side and the role of technology-push policies. Additionally we provide a summary on methodological approaches to measure policy efforts and technological change respecting different impact levels and stages within the technological change process. Finally, by focusing on international competitiveness and technology cost we highlight two aspects of the effects renewable technology innovation and respective policy support.
\end{abstract}

JEL: N70; 031; 032; 057 


\section{Contents}

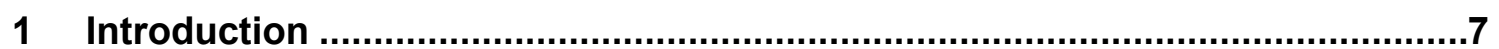

2 Energy market failures, externalities and government intervention ................8

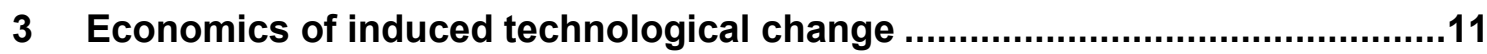

3.1 Market forces and technological change $\quad$......................................12

3.2 Policy intervention and technological change .............................13

4 The role of policy instruments in promoting RET technological change .......16

4.1 Market-pull policies............................................................. 16

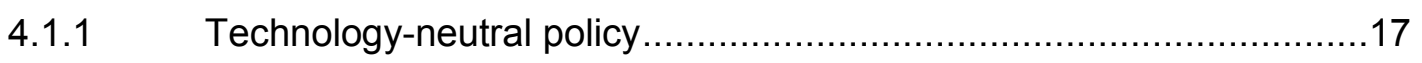

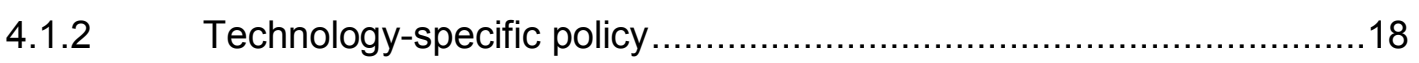

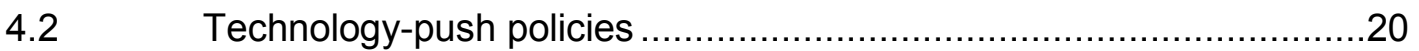

4.3 Policy mix of market-pull and technology-push policies ....................21

5 Methodological approaches to measuring policy efforts and technological

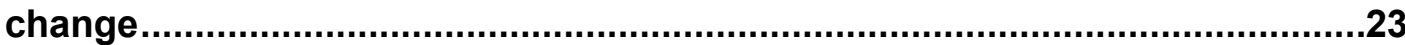

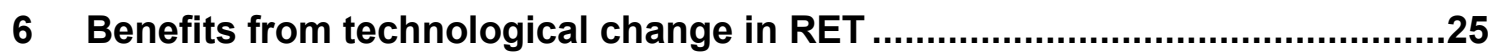

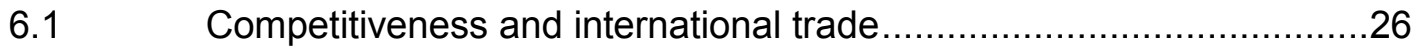

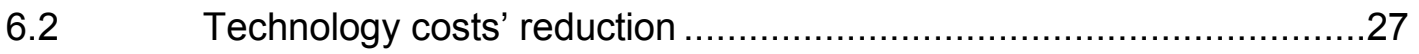

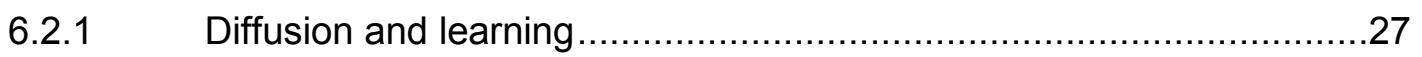

6.2.2 Learning and technology costs .............................................28

6.2.3 Findings on learning rates .................................................... 30

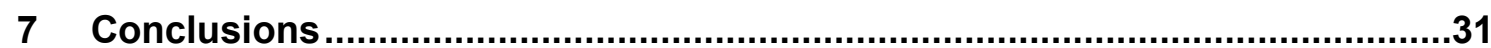

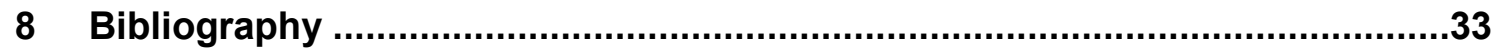




\section{List of Tables}

Table 2.1: Summary of selected market failures and barriers to renewable energy innovation, adoption and diffusion.

Table 3.1: Factors for technology invention, innovation, adoption and diffusion

Table 4.1: Strategies and selected policies for the promotion of renewable energy

Table 5.1: Overview of measures of inputs (determinants) and outputs of invention and innovation

\section{List of Figures}

Figure 4.1: Innovation chain and required policy types................................... 22

Figure 5.1: Aspects of measuring innovation................................................. 24

Figure 6.1: Diffusion, learning and technology costs ...................................... 31 


\section{Abbreviations}

$\mathrm{CO}_{2} \quad$ Carbon dioxide

$\mathrm{CO}_{2} \mathrm{e} \quad$ Carbon dioxide equivalent

IEA International Energy Agency

IPCC Intergovernmental Panel on Climate Change

RET Renewable Energy Technology

PACE Pollution Abatement and Control Expenditure

R\&D Research and Development

OECD Organization for Economic Cooperation and Development

EU European Union

ETS Emission Trading Scheme

$\mathrm{SO}_{2} \quad$ Sulphur dioxide

PV Photovoltaic

RES-E Electricity from Renewable Energy Sources

FIT Feed-in Tariff

LCOE Levelized Cost of Electricity 


\section{$-6-$}




\section{Introduction ${ }^{1}$}

Climate change induced by increasing carbon dioxide $\left(\mathrm{CO}_{2}\right)$ emissions caused by economic development is a serious challenge (IPCC, 2007). Substantial efforts are required to limit the concentration of $\mathrm{CO}_{2}$ equivalents $\left(\mathrm{CO}_{2} \mathrm{e}\right)$ to a level that avoids serious temperature increases and the subsequent dramatic effects on economic performance, welfare, and ecosystems (Stern, 2007). Increased adoption and diffusion of renewable energy technologies (RET) is critical in this context (Stern, 2007, IPCC, 2011). The appeal of renewable energy has risen due to its potential for reducing dependence on energy imports (Valentin, 2011). At the same time, renewable energy offers possibilities for generating local environmental and health benefits along with the facilitation of energy access (Mahapatra et al., 2009) and can have positive impacts on employment, competitiveness, and sustainable or "green" growth (Ragwitz et al., 2006, Council, 2009, Edenhofer and Stern, 2009, OECD, 2010, 2011).

In this context, technology advances and technological changes play an important role as they should help to lower technology costs which in turn should lead to increased market penetration of RE technologies. Hence, technological development should be accelerated in order to make low carbon or RETs cheaper, more efficient and better adapted to large-scale use (Jaffe et al., 2001, Hoffert, 2002, Vollebergh and Kemfert, 2005, Braun et al., 2010, Acemoglu et al., 2012). However, the rapid adoption and diffusion of renewable energies is being hampered by multiple obstacles. Research in this field documents numerous market failures and barriers ranging from unfavourable pricing mechanisms, high costs and risks, limited transmission access, as well as non-consideration of concomitant benefits (Painuly, 2001, Beck and Marinot, 2004). The objective of this paper is to give a short summary of these obstacles and a thorough literature review of the research analysing the impact of policies as well as the other driving forces aimed at fostering technological change of RETs. Additionally, we discuss several measures that strive to assess or quantify policy efforts and their impact on technological change. We also highlight the potential benefits resulting from innovation in RET.

The paper is organized as follows. Section 2 provides an overview of energy market failures and barriers, and the justification for government intervention. Section 3 presents the theory behind and the evidence for the impact environmental regulation on technological change, outlining the link between market forces, policies and technological change in general. Section 4 focuses on technical change in renewable energy and presents literature discussing the role of policies, especially market-pull and technology-push policies, as well as technology-neutral or

\footnotetext{
${ }^{1}$ Parts of the literature survey were compiled and used for Groba (2013) - Renewable Energies' Dissemination and International Trade - An Empirical Assessment of Policy, Markets and Innovation, Doctoral Dissertation Technical University Berlin, Berlin.
} 
technology-specific promotion schemes. Additionally, this section presents an overview of findings in the literature with respect to the importance of the mix and design of policy measures. Section 5 provides a summary of the indicators generally used in the literature to assess technological change and the respective promotional policies. Selected benefits from technological change in RET are presented in Section 6 and Section 7 concludes.

\section{Energy market failures, externalities and government intervention}

The theoretical literature suggests that government intervention in terms of regulation and implementing environmental policies is necessary in order to correct for externalities (Weitzman, 1974). In this context, market failures are understood to be deviations from perfectly functioning markets under neo-classical assumptions. Pricing mechanisms are incomplete as either consumption cannot be restricted or costs cannot be completely internalised. Market barriers can be defined as any disincentive discouraging market entrance or participation and the use or adoption of a good (Brown, 2001). This is not necessarily linked to the functioning of the market as such (Jaffe and Stavins, 1994, Jaffe et al., 2004).

This section gives a brief overview and Table 2.1 summarizes the identified market failures and barriers with respect to the innovation, diffusion and adoption of renewable energy technologies (RET).

Table 2.1: Summary of selected market failures and barriers to renewable energy innovation, adoption and diffusion.

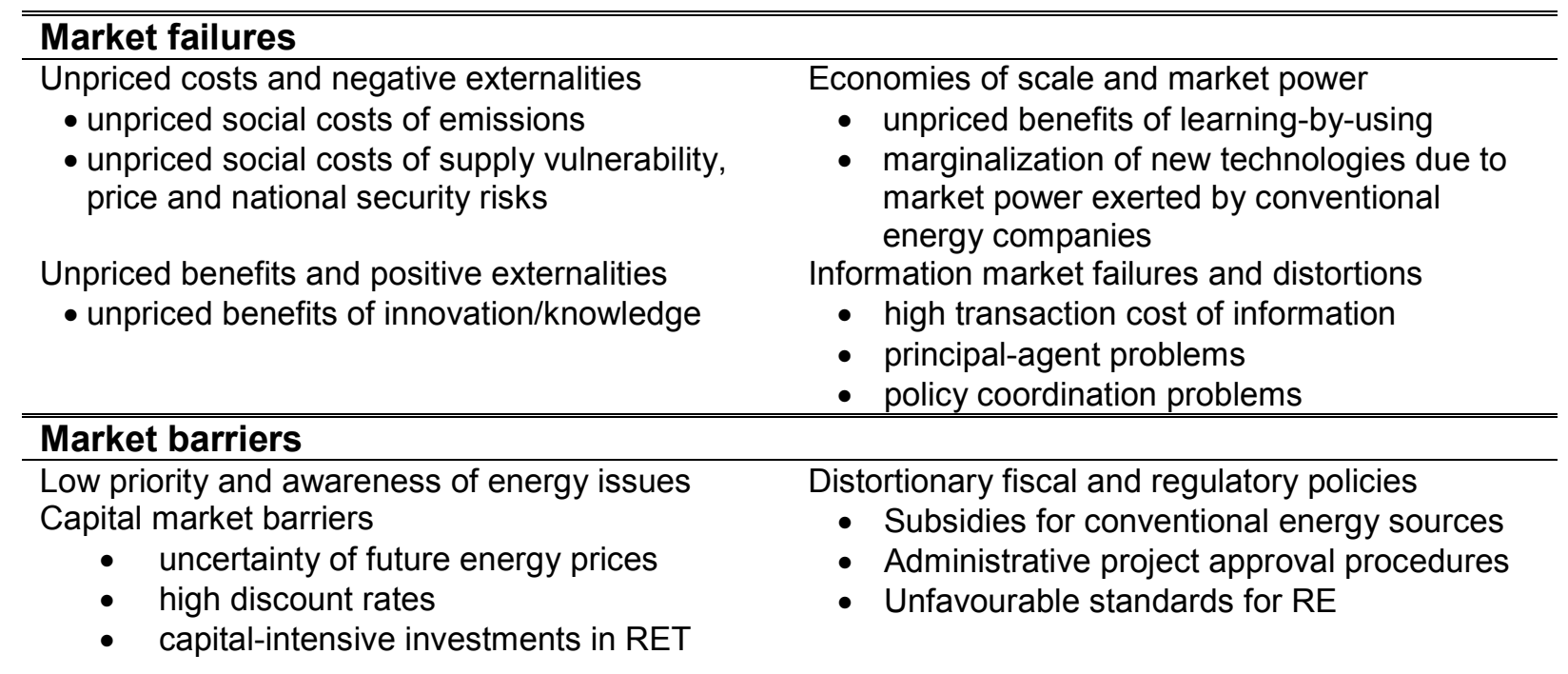

Sources: adopted from Brown (2001) and extended by the authors according to Mitchell et al. (2011), Beck and Marinot (2004), Menanteau et al. (2003) and Painuly (2001). 
Unpriced costs or negative externalities: A major market failure is that prices of fossil fuels generally do not adequately reflect a variety of associated social costs. The absence of an adequate price for fossil energy fuels results in these goods being consumed above social optimum (Brown, 2001, Gillingham and Sweeney, 2010). Without policy intervention, emissions from fossil fuel combustion are not priced at social optimum due to the public good character of clean air and the environment (non-exclusion criteria). A negative environmental externality arises as the social costs of greenhouse gases (GHGs) exceed the private costs of emission. Consequently, substitutes for fossil fuels, such as renewable energies, will be underused if incentives to invest in alternatives are not provided by mitigating external costs (Owen, 2006). Another negative externality is supply vulnerability and its associated price along with national security risks linked to oil and gas imports (Bohi and Toman, 1996). Costs associated with these risks, such as increased military and diplomatic expenditures, are not adequately reflected in fossil fuel energy prices. As a result, without policy intervention, companies do not take into account the social costs of emissions or potential supply shocks and, consequently, do not sufficiently invest in alternatives (Egenhofer et al., 2004).

Unpriced benefits or positive externalities: Knowledge generation in clean energy technologies accrues benefits to society, but this is often underprovided due to spillovers to others that prevent knowledge-generating firms from capturing the full economic benefit of their investment. Knowledge, as such, is non-rivalrous in consumption as there is no marginal cost to others who benefit from it. At a zero price, however, no knowledge is generated, as resources are necessary to acquire it. Furthermore, knowledge is, to some extent, nonexcludable as it can diffuse to other market participants at very low cost (Stiglitz, 1999). The creation of knowledge through research and development (R\&D), for instance, generates positive externalities as it generates societal benefits without incurring consumption costs for everyone. This risk of innovation leakage and benefit exploitation by competitors also implies that individual firms cannot capture the full economic benefits of their R\&D efforts, leading to significant underinvestment from a social point of view (Arrow, 1962, Jaffe, 1986, Nordhaus, 2002, Jaffe et al., 2005, Popp, 2006). Consequently, policy intervention is required in order to assure adequate intellectual property rights and provide incentives to generate knowledge and innovate while allowing sufficient, socially beneficial knowledge diffusion.

Economies of scale and market power: Another market imperfection prevails in energy markets where increasing returns and significant learning-by-using effects are relevant. Competition between conventional energy sources and renewable energies would be highly unprofitable for the latter without policy intervention to ensure that producers can capture the gains of future cost 
reductions induced through learning-by-using (Neuhoff, 2008). In markets, especially network markets with increasing returns, even inferior technologies that have been adopted might have initial advantages over new, superior technologies to the extent that the invention and adoption of new technology is discouraged (Katz and Shapiro, 1985, Arthur, 1989, Acemoglu et al., 2012). Hence, historically grown vertically integrated utilities can effectively exercise market power to the detriment of small or renewable energy facilities with special characteristics such as decentralized production and intermittency (Neuhoff, 2005, Jamasb and Pollitt, 2008). Additionally, conventional energy companies exhibit organizational strength and networks that allow them to use lobbying power against renewable energy policy design and enactment (Hughes, 1986, Mitchell et al., 2011).

Information market failures and distortions: The adoption and diffusion of fossil fuel saving technologies at a non-optimal level is often linked to mechanisms related to markets with information failures (Jaffe and Stavins, 1994, Levine et al., 1995). Neoclassical market efficiency assumes free and perfect information. However, in reality, the transaction costs for consumers associated with information collection and decision-making complexities are high, especially with regard to clean energy investment and consumption (Brown, 2001). With respect to nascent technologies, however, information plays an important role (Young, 2010). For instance, the uncertainty associated with the return on investment in innovation is often particularly large and constitutes an obstacle to upping innovative efforts (Scherer et al., 2000). In this context, the principal-agent problem is another market failure because, for instance, landlords and tenants have diverging incentives to invest in distributed renewable energy generation and energy efficiency. For example, although tenants are likely to benefit from investment, landlords are not compensated for the costs they bear, which results in considerable underinvestment (Levinson and Niemann, 2004, Murtishaw and Sathaye, 2006). Another type of market distortion is the failure to coordinate activities when building up a successful business, e.g. developing a new technology. Simultaneous investments are necessary in machinery and material manufacturing and training, but a lack of coordination among the different economic actors can have a negative impact on markets and economic development (Kydd and Dorward, 2004).

Market barriers: Other obstacles to renewable energy technology diffusion are related to the often low interest and awareness of policy makers, producers and consumers when it comes to energy issues, capital market barriers, as well as distortionary fiscal and regulatory policies, and the coordination among institutions (Brown, 2001, Henriques and Sardorsky, 2008, van den Bergh and Bruinsma, 2008, IPCC, 2011). Capital market barriers, such as uncertainty about future energy prices, lead to higher perceived risks and, thus, to strict 
investment criteria with hurdle rates that reduce investment (Hasset and Metcalf, 1993, Sanstad et al., 1995). Additionally, due to high upfront investment costs for renewable energy facilities, the discount rates for firms investing in fossil fuel extraction are considerably lower than the discount rates for companies investing in renewable energies. This results in considerable underinvestment in renewable energies relative to the economically efficient level (Gillingham and Sweeney, 2010). Distortionary fiscal and regulatory policies in the form of subsidies for conventional energy services, time consuming, slow or drawn-out administrative procedures for project approval, and unfavourable standards also discourage investment (Ragwitz et al., 2005).

The subsequent sections highlight the important role that policy intervention plays in reducing these market failures and barriers. Focusing on the market failures and barriers inhibiting technological change, we first describe the concept of technological change in general (Section 3) and, in more detail, the characteristics and effects of the different policies for supporting technological change in RET (Section 4). It becomes apparent that the challenges for policy makers are manifold, as they have to balance multiple market failures and respective policies that are likely to trigger opposition from interest groups. Furthermore, they have to weigh up political objectives and the costs that these policies are likely to incur (Haas et al., 2004, Aldy et al., 2010).

\section{Economics of induced technological change}

Technology has a strong impact on economic growth and determines how society's economic activity affects the environment. Research on technological change therefore has a long tradition. Before examining the effect of policy on renewable energy innovation, it is necessary to integrate this analysis into more general research on the topic. This section defines our understanding of innovation and describes the theoretical and empirical research on the impacts of technological change on environmental or energy technologies in general. In this context, the roles of market forces and policy are also highlighted.

In economics, technological change is understood as the static shift in the production possibility frontier (Solow, 1957) and as the gradual, more dynamic process from the creation of new technology to its commercial introduction to the market place (Schumpeter, 1934, Jaffe et al., 2001, Braun et al., 2010). In this context, this paper follows Jaffe et al. (2001) and uses the term invention to refer to the development of a new product and innovation to denote the successful commercial introduction of a new product to the market. Furthermore, diffusion is used to describe the process by which a successful innovation gradually becomes 
widely available for use through its adoption by firms and individuals. Collectively, we understand the process of technological change to be the cumulative economic and environmental impact of a new technology as it progresses through these three stages.

Environmental economics research on technological change has grown considerably, emphasizing the need to address the public good character of knowledge as well as negative externalities from fossil fuel combustion by means of government intervention (Popp et al., 2010). Much of the literature draws its motivation from the induced innovation hypothesis, which proposes that the direction of technological change corresponds to the direction of change in relative prices that can be influenced by policy (Hicks, 1932, Jaffe et al., 2003, Vollebergh, 2007).

\subsection{Market forces and technological change}

Early energy-economic models treated technological change as exogenous (Popp et al., 2010 provide a comprehensive literature overview of this topic). However, technological change is increasingly being conceptualized as endogenous - the result of decisions made by market participants responding to economic incentives such as prices (Romer, 1990, Aghion and Howitt, 1997, Acemoglu, 2002). Newell et al. (1999), for instance, test the induced innovation hypothesis by examining the effect of price changes on the energy efficiency of consumer durables. The analysis estimates product characteristics for durables like gas-fired water heaters and air conditioning units in the US between 1958 and 1993. They find that the rate of overall innovation is independent of prices and regulation, but that energy price changes impact the direction of innovation for some products. By differentiating alternative energy and energy efficiency technologies into 11 categories and analysing their impact factors, Popp (2002) finds that energy prices and the past stock of knowledge based on patents have positive effects on current innovation. Similarly, Crabb and Johnson (2010), using a dynamic model to represent innovation in energy-efficient vehicle technology from 1980 to 1999 , confirm that fuel prices are a major driver of innovation.

While these studies focus on the role of prices on innovation, there are also a large number of studies on the role of prices for the adoption of clean energy technologies. For instance, Rose and Joskow (1990) find that fuel-saving technology is adopted by US electricity generators in response to increasing fuel prices. Similarly, Jaffe et al. (1995) show that the adoption of thermal insulation technology positively responds to energy prices. However, they also show that underinvestment in new technology is also likely, because increased energy prices are often perceived as temporary. Focusing on US manufacturing industries, both Pizer et al. (2002) and Linn (2008) show that energy price increases trigger the adoption of specific energysaving technologies. 
In conclusion, the research on the effect of market forces highlights the fact that the rate and direction of technological change is induced by relative prices. In the light of existing externalities and knowledge market failures, it is widely accepted that government intervention is required to correct the market (Weitzman, 1974). Hence, policy that induces purposive changes in the relative prices is necessary (Vollebergh, 2007).

\subsection{Policy intervention and technological change}

In view of the market failures outlined in section 2, much of the literature analysing the relationship of market forces and technological change also investigates the effects of policy intervention. Here, it is important to highlight the debate about the path of technological change and the subsequent implications about which incentives are necessary and which types of policy are the most suitable. While some argue that several breakthrough technologies will emerge if policy concentrates on investing in technological inventions (Wigley et al., 1996, Hoffert, 2002), others underline the incremental character of past innovations (Fri, 2003, Neuhoff, 2005) and the importance of setting incentives to induce innovation through private profit-making investment activity (Grubb et al., 1995, Dowlatabadi, 1998, Jaffe et al., 2003, Popp et al., 2010). In light of accelerating climate change, others emphasize the need for early abatement efforts by creating technology demand and supporting learning-byusing (Stern, 2007, Fischer and Newell, 2008, Gerlagh et al., 2009).

Theoretical research on technical change suggests that environmentally-friendly innovation is induced more by market-based policies such as tradable permits than by command-and-control policies such as performance or technology standards. ${ }^{2}$ Command-and-control measures are seen as problematic as investment appropriation is not sufficiently guaranteed (Popp et al., 2010) and technology lock-in is possible as there are no incentives to exceed the control target (Hahn and Stavins, 1991). Magat (1978), working with an innovation possibilities frontier model of induced innovation, in which research augments capital and labour in the production function, and Millimen and Prince (1989) find that emission taxes or emission trading are superior policy instruments to technology or emission standards for inducing technological change at the firm level, because additional returns from innovation can be generated that reduce the cost of regulatory adjustment. However, Magat (1979) and Montero (2002) also show that, under strategic interaction in a Cournot market model, emission standards might induce greater R\&D incentives. Fischer et al. (2003) highlight that the effect of a policy on innovation and technology adoption depends, among other factors, on the innovators' ability to appropriate spillovers of related new technology, on the cost of technology and the number of competitors.

\footnotetext{
${ }^{2}$ Popp et al. (2010) provide a comprehensive review of the theoretical literature regarding policy choice and induced innovation in environmental technologies.
} 
Similar to the theoretical literature on policy-induced innovation, the empirical literature analyses the effect of different policies and their design and thus policy choice. Lanjouw and Mody (1996) compared 17 countries including the US, Japan and Germany and found that increases in pollution abatement costs and expenditures (PACE) induce increased patenting activities in environmentally-friendly technologies. Similar results based on studies using PACE are found in Hamamoto (2006) for private R\&D spending in Japan and in Brunneimer and Cohen (2003) for environmental patents in several US industries. Focusing on environmental technology patents, Hasics et al. (2012) find that private PACE leads to increased environmental patenting, contrary to public abatement spending. But they also show that governmental R\&D appropriations lead to an increase in environmental patents. Specifically, several studies compare the effect of market-based approaches with command-and-control measures. Jaffe and Stavins (1995) test the influence of mandatory and voluntary building standards, energy taxes, and subsidies on the diffusion of energy-saving technologies in US households between 1979 and 1998. They find that energy price expectations have a positive but diminishing effect. They conclude that price-based instruments such as energy taxes and technology subsidies may strongly stimulate adoption as they help to overcome technology cost disadvantages. They also show that the implemented building standards did not affect investment decisions about insulation, which suggests that these commandand-control instruments have been ineffective due to their non-binding character and setting criteria below existing standards. Hasset and Metcalf (1995) show that tax credits were effective in inducing insulation retrofits in the US. With respect to policy choice, the study of Newell et al. (1999) is of interest because it compares the effect of energy price-based policies, efficiency standards, and labelling. It shows that the effect of price changes on innovation is significant, especially after the introduction of energy-efficiency product labelling, while regulation via standards does not induce innovation. Similarly, Crabb and Johnson (2010) find no effect of efficiency standards and thus conclude that a gasoline or carbon tax may be a particularly effective regulatory tool to induce climate-friendly innovation in the automotive industry as this enhances the price effect. Analysing policy choice, several studies focus on the change in sulphur dioxide $\left(\mathrm{SO}_{2}\right)$ regulation in the US marked by the Clean Air Act in 1990, which introduced $\mathrm{SO}_{2}$ emission permit trading. Popp (2003) compares innovation before 1990 under command-and-control regulation and after 1990 in a market-based regulatory environment. He finds that innovation is higher before the introduction of permit trading, but that the type of innovation also changed. While innovation by US firms was only cost-saving oriented under command-and-control regulation, innovation under permit trading targeted both cost savings and emission reductions. Taylor et al. (2003), who analysed the effect of scrubber requirements on patenting technologies to reduce $\mathrm{SO}_{2}$ emissions, find that this command-and-control policy instrument had a negative effect on innovation. But they also note that the 
effect on regulated firms is ambiguous as most innovators are third party equipment suppliers (Taylor, 2008).

Additionally, several studies find that the stringency, commitment and consistency of policies may be more influential than the policy type. Jaffe and Palmer (1997) explore the effect of regulatory stringency on the innovative activity of US manufacturing firms between 1975 and $1991 .{ }^{3}$ Measuring innovation in terms of both R\&D spending and successful patent applications yields ambiguous results: regulation has a positive effect on R\&D but not on patenting activity. Kerr and Newell (2003) empirically show that increased policy stringency boosted the adoption of lead-reducing technology in US oil refineries. Lanoie (2008), using a survey in seven OECD countries, finds that greater stringency of regulation induces firms to invest more in environmental R\&D. The results suggest that market-based instruments induce less private R\&D spending, as these tend to be less stringent than environmental standards. Additionally, he finds that flexible standards which require certain environmental performance levels but do not define how to achieve them induce more environmental R\&D than pure technology standards. Similarly, Johnstone and Hascic (2009) use pollution control patent data to demonstrate that flexible policies lead to higher quality innovations as they allow firms to choose from among different options to comply with environmental regulation. White et al. (2013) show that unexpected changes in policies can have negative impacts on investment decisions in the cases of Norway and Ontario. Lipp (2007) compared the different renewable energy policies of Denmark, Germany and the United Kingdom. The results suggest that policy design and commitment are key factors for the successful deployment of RE technologies.

The conclusions drawn from theoretical models attempting to rank policy instruments according to their innovation stimulus and from the empirical literature remain ambiguous and depend on several factors (Fischer et al., 2003, Popp et al., 2010). Summarizing these factors in Table 3.1 highlights several decisive issues concerning both the market environment in which technological change occurs and the policies aimed at supporting that change.

Table 3.1: Factors for technology invention, innovation, adoption and diffusion

\begin{tabular}{c|l}
\hline \hline Policy & Market \\
$\begin{array}{l}\text { - Policy type } \\
-\quad \text { Market-based (tax, trading) }\end{array}$ & - Mechnology type and costs \\
$-\quad$ Command-and-control (standards) & - Relative firm-level incentive \\
$-\quad$ Information (labelling) & - Innovative ability of firms \\
- Policy stringency, commitment, & \\
consistency and flexibility & \\
\hline
\end{tabular}

\footnotetext{
${ }^{3}$ For different measures of policy stringency see Section 5.
} 


\section{The role of policy instruments in promoting RET technological change}

The market failures and barriers outlined in Section 2 have a cumulative effect, i.e. they occur at the same time, are interdependent, and individually provide motivation for corrective policy intervention aimed at implementing effective and efficient policies. The literature shows that firms have no incentive to adopt costly pollution control or renewable energy technologies if the missing internalisation of social costs due to market failures is not addressed. Furthermore, the literature above provides broad evidence that regulation may be a primary driver of clean energy technology innovation and adoption, but that policy choice and design are also decisively influential (Gray and Shadbegian, 1998, Kerr and Newell, 2003, Snyder et al., 2003, Popp et al., 2011). Depending on the type of market failure and the policy goal being pursued by public authorities, a variety of instruments and policies promoting renewable energies are available (Table 4.1).

In general, these policies can be differentiated into market-pull and technologypush. Technology-push policies primarily aim at increasing the incentives for firms to generate new knowledge and, hence, develop new RETs or improve existing ones by reducing the negative effects caused by the imperfect appropriability of benefits from innovation. Market-pull policies aim to increase the demand for renewable energies by internalizing negative externalities or reducing market barriers. The following discussion highlights the fact that both approaches are crucial in the context of renewable energies and technological change.

\subsection{Market-pull policies}

Market- or demand-pull policies aim at increasing renewable energy use by creating demand for RETs. The environmental economics literature generally agrees that market-pull policies not only boost the utilization of technologies but also induce innovation (Newell et al., 1999). These policies can generally be differentiated into market-based approaches and command-and-control measures. Market-based approaches encourage firms to innovate through market signals and incentive setting, which still leaves them the flexibility to choose the least costly options. Command-and-control policies, such as technology standards, leave relatively little room to manoeuvre as they principally comprise explicit directives and performance standards (Popp et al., 2010). Market-pull policy options for increased renewable energy deployment can take several forms, as they must not specifically focus on innovation but rather on the adoption and diffusion of renewables. Policy options include quantity- and price-driven measures that are either neutral or target specific technologies. The introduction of a carbon tax, for instance, is a non-technologyspecific, price-driven approach, while the establishment of a carbon trading scheme is technology-neutral but quantity-driven, because the quantity is set by a limit on 
emission allocations and the price of carbon is determined by the market. Similarly, the introduction of feed-in tariffs (FIT) is understood as a technology-specific, pricedriven approach, while renewable portfolio standards or quotas can be seen as a technology-specific, quantity-driven policy measure. ${ }^{4}$ Additionally, fiscal incentives such as grants and rebates and a supportive tax policy reduce the costs and risks of renewable energy investments by lowering the upfront investment costs (Sawin, 2004, Mitchell et al., 2011). Similarly, public finance can help to directly or indirectly mobilize and create commercial investment in renewable energy projects by reducing the investment risks through loans, guarantees or a long-term commitment to direct public investments (UNEP, 2008).

\subsubsection{Technology-neutral policy}

In theory, indirect, technology-neutral policies such as pricing carbon through taxes or emission trading schemes (ETS) result in cost-efficient mitigation measures, provided no further market failures exist (Rosendahl, 2004, Stern, 2007, Fischer and Newell, 2008). Establishing a carbon price through a technology-neutral, market-based approach like the ETS provides dynamic incentives for low carbon innovation (Fischer, 2005), which is thus, in theory, superior to a command-and-control measure in spurring innovation (Jaffe et al., 2002, Vollebergh, 2007, Popp et al., 2010).

Empirical evidence with respect to the innovation effect of ETS, however, is limited, especially with respect to renewable energies (Hoffmann, 2007, Rogge and Hoffmann, 2010). Empirical studies which do find evidence that innovation is induced by technology-neutral, demand-pull policies have mostly focused on the innovative effect of the US $\mathrm{SO}_{2}$ trading scheme, which was introduced in 1990 as outlined above. Popp (2003), for instance, finds a positive effect of the US sulphur emission trading on pollution control innovation. Taylor et al. (2005) conclude that both marketbased, demand-pull policies and command-and-control measures induce innovation. With respect to the EU ETS, Gagelmann and Frondel (2005) find that the potential innovation effect was limited in its early phase (2005-2007) due to the large, free emission allocations and unrestricted Clean Development Mechanism (CDM) and Joint Implementation (JI) credit use. In a qualitative study, Rogge and Hoffmann (2010) find that the EU ETS does affect the rate and direction of technological change of power generation technologies in large-scale, coal-based power generation, but only marginally with respect to renewable energies. Egenhofer et al. (2011) underline that the carbon price and its volatility under the EU ETS is an important element for investment decisions in climate-friendly innovation, but that low prices, the uncertainty of price development and over-allocation of emission rights

\footnotetext{
${ }^{4}$ In this paper, the differentiation between technology-specific and non-technology-specific policy is made with respect to renewable energies in general. Hence, policies supporting renewable energy in general that are not differentiated by measures for specific technologies such as solar, wind and biomass (i.e. quota without banding) should not be confused with non-technology-specific.
} 
undermine the predictability of the market scheme and require separate renewable energy policies. Similarly, based on case studies in the German power sector, Rogge et al. (2011) find that the impact of the EU ETS on innovation has remained limited due to the lack of stringency and predictability providing insufficient incentives for corporate innovation activities. They also point out the importance of market factors and the variety of impacts across technologies and firms which highlight the need for an appropriate mix of additional policies to overcome environmental and innovation market failures. Recently, Schmidt et al. (2012) have added empirical evidence to the theoretical and case study literature. They find that the EU ETS has limited effects on innovation, but that long-term emission reduction targets and additional technologyspecific policies are important innovation determinants at the corporate level.

\subsubsection{Technology-specific policy}

Although the debate is on-going about the contribution of renewable energy support schemes to emission reduction and the effect of additional technology-specific policies on the cost-effectiveness of emission trading, many authors highlight that direct, technology-specific support policies for renewable energies, like feed-in-tariffs, are necessary complements in the light of the knowledge about market distortions and path dependency in socio-technical systems (Haas et al., 2004, Sijm, 2005, Bennear and Stavins, 2007, del Rio, 2009, Gerlagh et al., 2009, Aldy et al., 2010, Lehmann and Gawel, 2013).

Technology-specific policies aim at increasing the specific demand for renewable energy technologies. Quantity-driven policies allow the market price to be determined by market transactions between actors while ensuring that utility operators generate or sell a predetermined amount of electricity from renewable energy sources (RES-E). The price is determined by the market and operating firms have a certain choice about which RET is used. Price-driven policies provide financial incentives for capacity expansion and direct generation. ${ }^{5}$ Additionally, voluntary programmes can be implemented which depend on the consumers' and producers' willingness-to-pay for or invest in renewable energy.

Numerous qualitative and empirical studies show a positive effect of RES-E support schemes on deploying renewable energy technologies for electricity generation (among others: del Río González and Gual, 2007, Lipp, 2007, del Río González, 2008, Lesser and Su, 2008, Yin and Powers, 2010, Haas et al., 2011, Dong, 2012, Groba et al., 2012). Yet the literature on the innovative effect of RES-E policies remains ambiguous concerning the suitability of different renewable energy policy types for inducing innovation.

\footnotetext{
${ }^{5}$ Mitchell et al. (2011) in the framework of the IPCC's Special Report on Renewable Energy Sources and Climate Change Mitigation give a broad overview on the economic classification of renewable energy policy types and their effect on market failures, along with a comprehensive literature overview.
} 
Table 4.1: Strategies and selected policies for the promotion of renewable energy

\begin{tabular}{|c|c|c|c|c|}
\hline \multicolumn{5}{|c|}{ Market-pull policies } \\
\hline & & \multicolumn{2}{|c|}{ Technology-specific (direct) } & \multirow{2}{*}{$\begin{array}{l}\text { Non-technology- } \\
\text { specific (indirect) }\end{array}$} \\
\hline & & Price-driven & Quantity-driven & \\
\hline \multirow[b]{2}{*}{$\begin{array}{l}\text { Market- } \\
\text { based }\end{array}$} & $\begin{array}{l}\text { Investment } \\
\text { incentives }\end{array}$ & $\begin{array}{ll}\text { - } & \text { Investment } \\
& \text { subsidies } \\
\text { - } & \text { Tax credits } \\
\text { - } & \text { Supportive tax policy } \\
\text { - } & \text { Tenders (price) } \\
\end{array}$ & $\begin{array}{l}\text { Tendering systems } \\
\text { for investment } \\
\text { grants (quantity) } \\
\text { - Quotas (capacity) }\end{array}$ & \multirow[b]{2}{*}{$\begin{array}{l}\text { - Environmental } \\
\text { taxes } \\
\text { - Emission trading }\end{array}$} \\
\hline & $\begin{array}{l}\text { Generation } \\
\text { incentives }\end{array}$ & $\begin{array}{ll}\text { - } & \text { Feed-in tariffs } \\
\text { - } & \text { Premium feed-in } \\
\text { tariffs }\end{array}$ & $\begin{array}{l}\text { - Energy portfolio } \\
\text { standards (quotas) } \\
\text { in combination with } \\
\text { tradable green } \\
\text { certificates } \\
\text { - Tendering systems } \\
\text { for long-term } \\
\text { contracts } \\
\end{array}$ & \\
\hline
\end{tabular}

Commandand-control
- Technology and performance standards

- Authorization procedures

\footnotetext{
Technology-push policies

- Public R\&D spending (direct funding, grants, prices)

- Tax credits to invest in R\&D

- Capacity enhancement for knowledge exchange

- Support for education and training

- Financing demonstration or pilot projects

- Market engagement/incentive programmes/public procurement

- Strategic development policies

- Technology exhibitions/fairs

- Network creation/building

Sources: adopted from various sources (Green, 2002, Menanteau et al., 2003, Grubb, 2004, Haas et al., 2004, Haas et al., 2008, Mitchell et al., 2011) and extended by the authors.
}

In general, Kemp et al. (1998) and Nill and Kemp (2009) suggest that government should use technology-specific, market-pull policies to create niche markets and protect new innovations from competition with established technologies. Peters et al. (2012) use the existing renewable electricity capacity as a proxy for market-pull policies and find that strong market-pull measures have a positive effect on the innovative output in a country based on patents. The environmental economics literature argues that quantity-based regulation (e.g. renewable obligations) is better suited to promoting positive externalities from innovation in climate-friendly technologies, because it incentivises competition between 
technologies and thus reduces costs (Jaffe and Stavins, 1995, Popp, 2002, Jaffe et al., 2003, Jaffe et al., 2005, Fischer and Newell, 2008). The public policy literature, on the other hand, notes that various aspects of policy design are crucial when assessing price-based policies (e.g. FITs) and quantity-based measures (e.g. renewable obligations). In this respect, comparative case studies find that long-term, reliable, government commitment is decisive (Langniss and Wiser, 2003, Sawin, 2004, Martinot et al., 2005, Haas et al., 2008, Klein et al., 2008). Most studies emphasize that this is better provided under a FIT mechanism, which is superior with respect to reducing prices and investment risks as well as with respect to supporting learning-by-using (Mendonca, 2007, Toke and Lauber, 2007). Mitchel et al. (2006), who compared renewable obligations and FITs in England and Germany, find that the latter are more effective at reducing investment risks for generators. Similarly, Butler and Neuhoff (2005), when comparing technology-specific policy support schemes in the UK (e.g. quota and tendering) and Germany (e.g. FIT), find that, despite similar policy costs and levels of competition, FITs reduce the costs to consumers resulting in larger RET deployment. They highlight that the uncertainty of financing under quota and tendering schemes reduces investment activity. However, looking at renewable energy technology innovation in terms of patents, Johnstone et al. (2010) compare price-based (feed-in tariff) regulation and quantity-based policies (quotas) and find important differences across renewable energy technologies. Lüthi (2010), who compares the German, Spanish and Greek photovoltaic (PV) markets, investigates factors determining policy effectiveness. He finds that risk-related factors (e.g. policy stability, administrative hurdles) are more important for determining PV investments than return-related factors (e.g. tariff level). Yet the literature also outlines that there are technological differences concerning the innovation effect of policies. For instance, in a seminal paper, Johnstone et al. (2009) examine patent data of 25 countries over the period from 1978 to 2003 and find empirical evidence that broad policies, such as tradable renewable energy certificates, are likely to induce innovation in technologies that are close to competitiveness with fossil fuels such as wind energy. However, they also highlight that targeted subsidies, such as feed-in tariffs, are required to induce innovation in more costly energy technologies like solar power. Hence, not only specific policies targeting renewable energies in general are required, but these policies should also be differentiated and designed to match the needs of specific renewable technologies.

\subsection{Technology-push policies}

In addition to the benefits that market-pull measures provide, technology-push policies, such as public research and development spending (R\&D) as well as fiscal measures that incentivise private R\&D, are important in order to internalize the benefits from innovations in climate-friendly technologies. Without adequate policy support, especially in the early stages of innovation, companies tend to underinvest 
in clean energy technologies, as they cannot exclude spillovers to competitors who have borne none of the development costs. Further, they tend to be risk averse if technology success is uncertain and the time span until market maturity is expected to be lengthy (Jaffe et al., 2005, Bürer and Wüstenhagen, 2009, Popp et al., 2010).

Several empirical studies demonstrate the positive effect of technology-push policies on innovation in the renewable energy sector. Watanabe et al. (2000) find a positive effect of public R\&D funding on innovation in the Japanese PV sector. They argue that this funding initiated a virtuous cycle between innovation, price reduction, market growth and supplementary industry R\&D spending. Klaasen et al. (2005) analysed the effect of public R\&D spending on wind energy technology innovation in Denmark, Germany and the United Kingdom. Based on a two factor learning curve model, in which investment cost reductions are explained by cumulative capacity and R\&D-based knowledge stocks, they find that the learning rates induced through R\&D are higher than the learning rates induced by using wind energy technology ${ }^{6}$. Johnstone et al. (2009), using patent counts as a measure of innovative output, find that public R\&D funding positively effects innovation in renewable energy technologies. Additionally, policy support is also required to incentivise private R\&D, as this is complementary to the impact from public R\&D (del Rio and Bleda, 2012).

The next section outlines that the best approach is actually a policy mix between technology-push and market-pull measures, as the innovation effects of $R \& D$ are greater for less mature technologies. Furthermore, private $R \& D$ investments require the creation of a market (Watanabe et al., 2000) with a producer surplus that is needed for reinvestments in R\&D (Butler and Neuhoff, 2005, Finon and Menanteau, 2008).

\subsection{Policy mix of market-pull and technology-push policies}

Some scholars such as Dowlatabadi (1998) and Grubb et al. $(1995,2002)$ highlight the importance of market-pull policies to incentivise technology diffusion through the market. Others, such as Hoffert et al. (2002), insist that technology-push policies are decisive for generating new technologies that can be brought to market maturity, i.e. at cost competitive levels. Yet both the theoretical and the case study literature agree that successful technological change in renewable energies requires a mix of technology-push and market-pull policies to induce innovation and expand renewable energy utilisation (Grubler et al., 1999, Grubb, 2004, Neuhoff, 2005, Jeroen C. J. M. van den Bergh and Frank R. Bruinsma, 2008, Bürer and Wüstenhagen, 2009, Johnstone et al., 2010).

By analysing the innovation chain from basic research, through applied R\&D, and demonstration to the commercialisation of a new technology, product or process,

${ }^{6} \mathrm{~A}$ definition of learning-curves is outlined in Section 6.2. 
Grubb (2004) highlights that policy support of varying intensity and direction is required. Grubb (2004) as well as Bürer and Wüstenhagen (2009) stress that public grants as well as basic and applied R\&D are required during the early phase of the innovation chain, while market-pull policies are necessary during later phases to reach full commercialisation (Figure 4.1). They also outline that a significant challenge for a new technology is to survive what they term the "valley of death" between demonstration, pre-commercialisation and niche market development. Similarly, Fischer (2008) develops a theoretical model showing that public R\&D support for emission control technology is only effective if environmental policy, in terms of market-pull measures, is in place to encourage technology adoption in the marketplace. Acemoglu et al. (2012), use a two-sector growth model with endogenous technical change and knowledge externalities to show that optimal regulation entails both a carbon price and a R\&D subsidy to encourage innovation in clean energy technologies. The study of Johnston et al. (2010), with an empirical analysis of innovation in renewable energy technologies, also highlights that both demand-pull and technology-push instruments have a significant influence on the development of new renewable energy technologies.

Figure 4.1: Innovation chain and required policy types

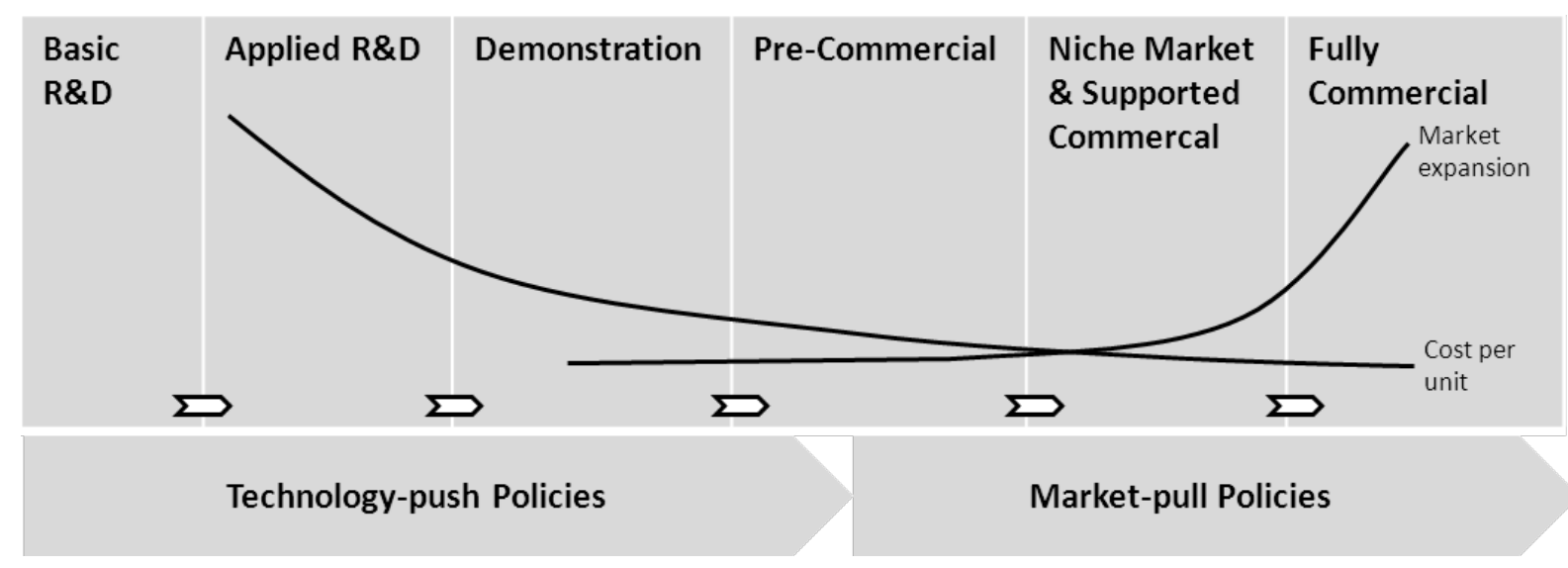

Note: adapted from Grubb, 2004

In the context of applying different policies to the various stages of technology development, the national system of innovation literature is also important. This provides a holistic picture of the role of institutions (market, research, education, other sectors), incentive structures, networks in the innovation process, and technology characteristics (Edquist, 2006). Its approach is well suited for comparative studies because it provides information about the heterogeneity of drivers, barriers and policy frameworks and technologies (Coenen and Diaz, 2010). Foxon et al. (2005) applied a system of innovation approach to the UK and found that wind onshore technology development here lagged behind other countries due to less 
favourable policies. Building upon this work, Foxon and Pearson (2007) then analysed policy processes in the UK and found that renewable obligations failed to promote RET innovation because this instrument, among other things, does not account for the different stages of technology development and commercialisation. Similar contributions come from Bergek and Jacobson (2003), who analysed the wind industry in Germany, Denmark and Sweden; Marinova and Balaguer (2009) who looked at the photovoltaic industry in Australia, Germany and Japan; Negro et al. (2007) who analysed the innovation system in Denmark focussing on biomass; and Hekkert et al. (2007) who explained the rapid diffusion of cogeneration technology in the Netherlands. Del Rio and Bleda (2012) show that FITs are likely to be superior to other policy instruments such as quotas, tradable green certificates and tendering. However, they also highlight that complementary instruments, specifically R\&D support, are also required and that the innovation effects depend strongly on specific policy design elements.

In conclusion, the literature identifies several crucial elements. National innovation systems and the mix of implemented policies are important determinants of the technological change process. In addition, specific policies targeted at respective technology development phases are required as much as technologyspecific promotion approaches to enhance the development of less mature technologies.

\section{Methodological approaches to measuring policy efforts and technological change}

This paper summarizes the literature on the effects of policy and market forces on technological change in RETs. The previous literature overview already showed that this research applies various indicators to assess invention, innovation and diffusion as well the stringency, consistency, commitment and level of policy support. This section gives a brief overview of these indicators and discusses their characteristics.

Assessing the role of policy in inducing technological change requires awareness of the dimensions involved (OECD, 2009). The literature reviewed above shows that some papers analyse innovation on the firm level, while others focus more on the effect of policy on innovation at a country level. Additionally, one has to differentiate between the drivers of and barriers to technological change, the elements of technological change, and, last but not least, between technological change as such and the impacts from it (Figure 5.1). 
Figure 5.1: Aspects of measuring innovation

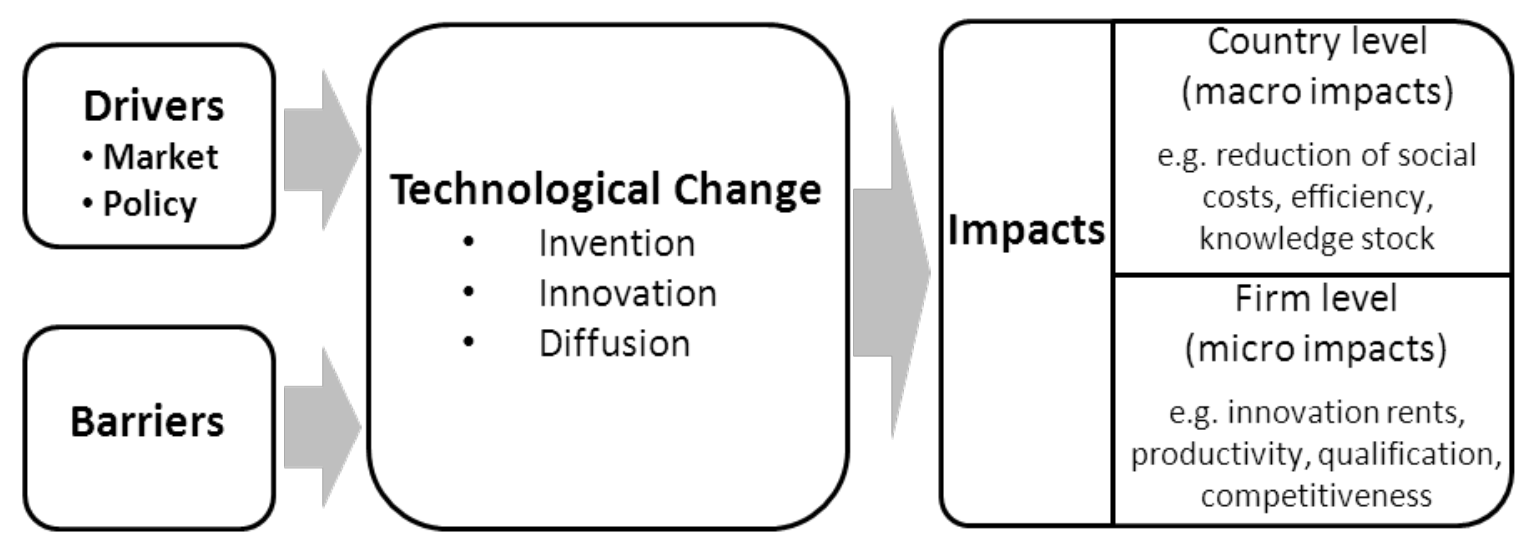

Note: adopted from OECD (2009).

The literature (for example in Breitschopf et al., 2005)) generally differentiates between input (resource) and output (yield) oriented measures of invention and innovation. Input measures ideally refer to the policy that is driving technological change. Output measures capture the results of the inventive or innovative process. Table 5.1 provides a summary of these measures.

Table 5.1: Overview of measures of inputs (determinants) and outputs of invention and innovation

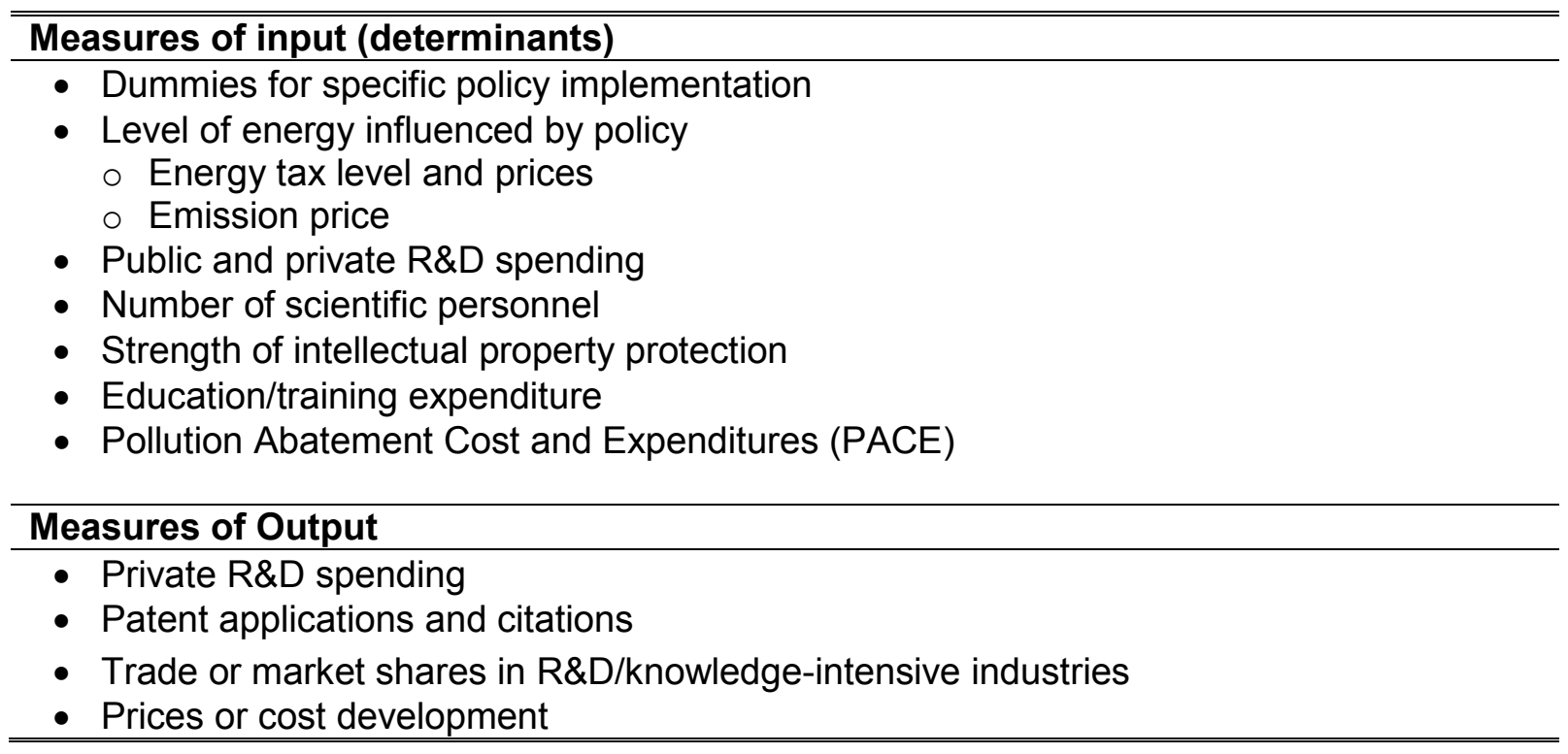

With respect to the input measures, researchers would ideally like to identify the relationship between innovation and the shadow price of environmental inputs into the production process, such as pollution (Popp et al., 2010). However, because this 
shadow price, which can be influenced by regulation as outlined above, is hardly observable in reality, alternative measures are required as a proxy for this price and the incorporated policy effect. Environmental policy characteristics, the prices of polluting inputs such as energy or the required pollution abatement expenditures (PACE) are used as such a proxy. The specific effect of newly introduced policies as well as policy stringency or strictness is often of interest. Van Beers and van den Bergh (1997) and Harris et al. (2002), for instance, applied an index as a policy measure. Countries are ranked based upon the absolute carbon intensity and the change in carbon intensity, with the lowest rank assigned to the worst performer.

Further typical variables used to assess input measures and thus the potential determinants of the innovative process are research personnel and R\&D spending. In this context, the level of private R\&D spending can be viewed as both an input and an output measure, as it represents an input to a company's innovation strategy and the result of supportive government policies. However, R\&D data is often not available in disaggregated technology terms. Hence, the literature highlights that R\&D spending might be insufficient as a measure, since this only reflects inputs into the innovative process without measuring the research output. Griliches (1990), Jaffe (1986) and Popp et al. (2011) show that patent data may be preferable as it provides disaggregated information on innovation in terms of technology type and inventor, thus providing meaningful alternative indicators of innovation and technology diffusion. Hence, patent applications, publications, but also new products and productivity improvements have become common measures to assess the output of innovative processes. Section 6 of this paper also discusses other output-oriented measures of innovation. First, trade in goods and services related to knowledgeintensive industries such as the renewable energy industry can potentially provide insights into the impact of scientific and technological activity on industrial and economic development and the competitiveness of certain firms and industries. Second, analyses of price and technology cost developments are also regularly applied in order to identify technological change processes as well as the role of respective policies.

\section{Benefits from technological change in RET}

This paper highlights the impact of energy prices and changes in energy policy on technological change in the area of renewable energy technologies. However, there is another stream of literature worth mentioning which analyses the effect of the induced innovation on two factors, technology costs, e.g. resulting cost reduction of RES-E and (technological) national as well as international competitiveness. ${ }^{7}$

\footnotetext{
${ }^{7}$ A more thorough analysis of these aspects is presented in working package 2 of the project "Impact of renewable energy Sources (ImpRES)", conducted by Fraunhofer ISI, DIW Berlin and GWS and IZES.
} 


\subsection{Competitiveness and international trade}

A key question in the context of environmental policy implementation is whether or not environmental regulation reduces or increases a country's competitiveness in international markets (Galeotti and Kemfert, 2004). In light of the European Union's Lisbon agenda, devised in 2000, and the implementation of "green" recovery programmes following the financial crisis in 2008 , the role of environmental policies and their potential to enhance competitiveness, resource efficiency and sustainable growth has attracted considerable attention in the academic literature and the public eye (Edenhofer and Stern, 2009).

Theoretical studies examining the interaction between international competitiveness and environmental regulation identify two opposing hypotheses. The pollution haven hypothesis postulates that increasing environmental regulation is harmful to industry productivity and competitiveness in terms of trade as it induces higher costs for production and thus for the final product (Copeland and Taylor, 2003, Brock and Taylor, 2005). The opposing argument is known as the Porter hypothesis and is based on the dynamic competitiveness theory. This suggests that environmental regulatory shocks can induce cost-saving innovations that compensate for compliance costs, thus positively affecting an economy's dynamic behaviour (Porter and van der Linde, 1995, van den Bergh et al., 2000). The strong interpretation of this hypothesis outlines that the efficiency gains and product enhancements induced by complying with environmental regulation can benefit the whole economy. Jaffe and Palmer (1997) introduce two other versions of this hypothesis. The weaker version argues that environmental regulation induces only certain innovations. This approach ignores the social value of innovation; the effects of reduced emissions on the economy and society are ambiguous. The narrowly strong version of the hypothesis suggests that stringent environmental regulation might only positively impact the domestic environmental (technology producing) industry and increase its competitiveness (Jaffe et al., 1995, Jaffe and Palmer, 1997). Yet they link this interpretation of the Porter hypothesis to its strong version by outlining that these specific gains in a particular sector can potentially outweigh the cost burden borne by other sectors. The dynamic approach taken within the Porter hypothesis framework also raises questions regarding the effect of regulation on early adopters and regulation laggards, as well as regarding the role of innovation dynamics in terms of imitation, adoption and learning-by-using. In this context, the lead market literature argues that early successful innovation in one country can be successfully commercialized in a global market as well (Cleff and Rennings, 2011). Thus, the lead market literature augments the weaker interpretation of the Porter hypothesis by suggesting that an early introduction of adequate technology support policies can create an industry with a competitive world market advantage (Beise, 2004, Beise and Rennings, 2005) if other countries follow the demand for climatefriendly technologies. 
There are various empirical studies of the pollution haven hypothesis and the Porter hypothesis, but their results diverge. There appears to be no robust empirical confirmation whether regulatory costs for firms are too high and negatively affect competitiveness, or whether environmental regulation induces innovation that compensates the cost of regulatory compliance for the whole economy (Antweiler et al., 2001, Harris et al., 2002, Grether and de Melo, 2003, Jug and Mirza, 2005). Furthermore, two studies by Lanoie et al. $(2008,2011)$, which did not focus on competition in terms of trade, found that environmental regulation positively impacts productivity in sectors exposed to international competition. Costantini and Crespi (2008) and Costantini and Mazzanti (2012) were the first to examine OECD and EU trade with energy technologies. They provide positive evidence for the weak and the narrowly strong Porter hypothesis showing that environmental regulation can be a significant source of comparative advantage.

However, when analysing sector-specific trade and competitiveness, the development of the technological regime and the degree of industry heterogeneity have to be taken into account (Cole et al., 2005, 2010). Currently, rather broad indices are being used based on regulation output measures such as emissions or energy intensity or the pollution abatement costs to firms (van Beers and van den Bergh, 1997, Harris et al., 2002, van Beers and van den Bergh, 2003, Costantini and Crespi, 2008, Constantini and Mazzanti, 2012), but these might not adequately assess the impact of renewable energy policy and, thus, do not necessarily reflect the impact on the renewable energy sector. Further research is required in this field.

\subsection{Technology costs' reduction}

This section gives an overview of literature discussing the relationship between technology diffusion, learning and technology investment costs. The idea behind this review is to see how well technological changes induced by diffusion or increasing deployment can be captured by changes in technology costs. The objective of this section is to shed some light on the following questions:

- Does technology diffusion (measured as cumulative production) impact learning-by-doing and scaling, both of which reflect technological change?

- Can learning-by-doing and scaling effects be captured by technology costs?

\subsubsection{Diffusion and learning}

Technological learning occurs at two levels: First, at the product level, e.g. size or efficiency increase of a PV module (product innovation) such that, in the case of electricity generation, the specific generation costs (LCOE) decrease. In this context, Wilson (2012) refers to up-scaling at the unit level that leads to a reduction of unit costs. Second, technological learning occurs along the production line of the product, through organizational changes, process innovations or learning-by-doing, so that the 
costs of producing the product (e.g. PV modules) decrease while, for instance, the product's efficiency might remain unchanged. Nevertheless, this normally entails a decrease in generation costs (final product) as well. Wilson (2012) calls this the learning effect at the industry level, which also includes manufacturing scale effects. He considers both effects - learning-by-doing and up-scaling - to be common characteristics of technology diffusion or cumulated production. This implies that increasing installations or the use of technologies will induce learning, up-scaling or innovations at the product and industry levels that in turn lead to decreasing costs. Likewise, Wilson (2012) states: "The influence of accumulating production experience on costs is captured by the concept of learning." He continues by stating that "learning is a descriptive label for a multi-faceted process of knowledge generation, application and exchange." In addition, market diffusion is a dynamic process with feedbacks (Kobos et al., 2006) to R\&D and other factors as well.

\subsubsection{Learning and technology costs}

Cost curves offer a common framework to conceptualize the production costs over time in order to analyse the cost reduction effects of policy induced diffusion. Experience curves are one technique used to estimate cost curves which depict the relationship between cumulative production (reflecting learning-by-doing) and the unit costs of a technology (Kobos et al., 2006). The Boston Consulting Group (BCG, 1968) developed this expression but added more parameters explaining the cost decrease. Experience curves are good tools to answer questions like "how much support a technology needs to become competitive,..." (IEA 2000). Furthermore, experience curves are a relatively simple approach to describe the historical development and performance of technologies and to assess the learning investments needed to make a technology competitive (IEA 2000). However, recent studies have provided evidence that technology costs are not determined solely by diffusion of the technology.

The study by Isoard and Soria (2001) shows that learning effects at industry level seem to be a significant driving force of productivity growth. Junginger et al. (2006) state that there is a fixed relation between learning and costs, i.e. the cost per technology unit declines at a fixed rate. Kobos et al. (2006) used a two factor experience curve approach and investigated the impact on costs of learning-by-doing (cumulated capacity), innovation and learning-by-searching (cumulated R\&D spending). The results suggest that cumulative R\&D expenditures are also important and should be included in the learning or experience curve. However, the findings are considered preliminary and the suggestion is to apply different formulations of the learning curve.

Söderholm and Sundqvist (2007) critically analyse the use and choice of modelling and estimation strategies for learning curves. Their results illustrate a large 
variation of estimations for learning rates depending on the model specification and approach used. Weis et al. (2010), Nemet (2006), Yeh and Rubin (2012) all drew similar conclusions.

Feriol et al. (2009) argue that learning-by-doing may impact the overall costs of a technology, but that the effects of single component improvements that have not yet been studied in detail could better explain the aggregated form of learning. They also point out that cost reductions may not continue indefinitely and that resource constraints or market barriers can limit the scope of further cost improvements. Regarding market constraints, Van der Zwaan et al. (2012) look at the price fluctuations of raw materials, among other things, that might increase costs. When abstracting from raw material prices they find a price reduction over time for wind offshore technologies that could be explained by economies of scale and learning-bydoing. In the case of wind and solar power, Feriol et al. (2009) investigate the impact of diverse factors like single (technical) components, public R\&D, trends over time, etc. on the learning rate. For example, only a few components of the technology might be driven by learning-by-doing while others are integrated in other technologies and depend on the respective rate there. They find that, in particular, the geographic coverage (international or national) has a significant influence on the learning rate. Overall, they conclude that empirical studies of energy technology learning rates provide hardly any uniform estimates about the magnitude of these rates.

Since the empirical evidence on wind turbine prices in the US runs counter to standard learning or experience curve analyses, Bolinger and Wiser (2012) look at other possible price drivers (e.g. labour costs, raw material prices, energy prices) of wind turbine prices - not their unit costs or LCOE. Their findings show that about 70$90 \%$ of the price changes can be explained by these factors. Exogenous factors like prices for energy and materials explain about $50 \%$ of price changes. Panzer (2012), who also analyses the impact of energy and raw materials on investment costs, finds that learning-by-doing effects are partly compensated by price factors. In Bolinger and Wiser's (2012) work, endogenous factors like labour cost, turbine scaling, etc. that should benefit from learning explained $50 \%$ of price movements. However, these include turbine scaling (26\%) that attributes to lower LCOE. So LCOE should be a better measure of learning effects than absolute turbine prices. This was applied by Hernández-Moro and Martínez-Duart (2013). They assess future LCOE based on the learning curve approach and IEA deployment scenarios for renewable energies. They derive specific policy recommendations by revealing the influence on LCOE of other factors such as solar resource, discount rate, operation and maintenance costs and lifetime of the system.

Moreover, Neji (1997), Grubler (2010) and Söderholm and Sundqvist (2007) argue that cumulative production is not only an exogenous variable but the result of falling costs and that learning is not solely determined by cumulative production but 
influenced by innovation activities and efforts at the industry level. Thus the experience curve represents a correlation between cumulated production and costs, but is not an established method to explain falling costs.

\subsubsection{Findings on learning rates}

The general objective of the literature is to see whether the potential impact of RE deployment or diffusion of $\mathrm{RE}$ technologies on innovation can be captured by changes in technology costs. Overall, the discussion in the literature about diffusion, learning and technology costs centres around using experience/learning curves or rates as an appropriate means to measure the cost of a technology depending on its diffusion. An overview of ranges of technology-specific learning rates as well as the geographic coverage and time range for energy technologies is given in Panzer (2012). They range from $7 \%$ for wind on-shore, $10 \%$ for wind off-shore to $20 \%$ for PV - all global - and $5 \%$ for biomass combined heat and power (in Sweden). A negative rate or a very high rate implies that other parameters, not taken into account in this study, are influencing the rate.

The main findings from the literature concerning the application of learning rates to technology cost assessments and hence to technology changes are depicted in Figure 6.1 and can be summarized as follows:

- Diffusion, expressed as cumulated capacity or production, entails learning and scale effects at the industry level as well as at the unit or product level.

- These learning and scale effects can be partly captured by an experience/learning curve that reflects the relation between cumulated production and unit costs. However, the results vary due to the influence of other drivers like technical components, geographic coverage, material and energy prices, R\&D spending, etc.

- Further, learning curves show a correlation but not a strong dependency between these factors. In other words, "learning is not a deterministic outcome" (Wilson, 2012) of cumulative capacity.

- Learning rates for renewable energy technologies are available and have been thoroughly discussed and analysed for wind and PV. 
Figure 6.1: Diffusion, learning and technology costs

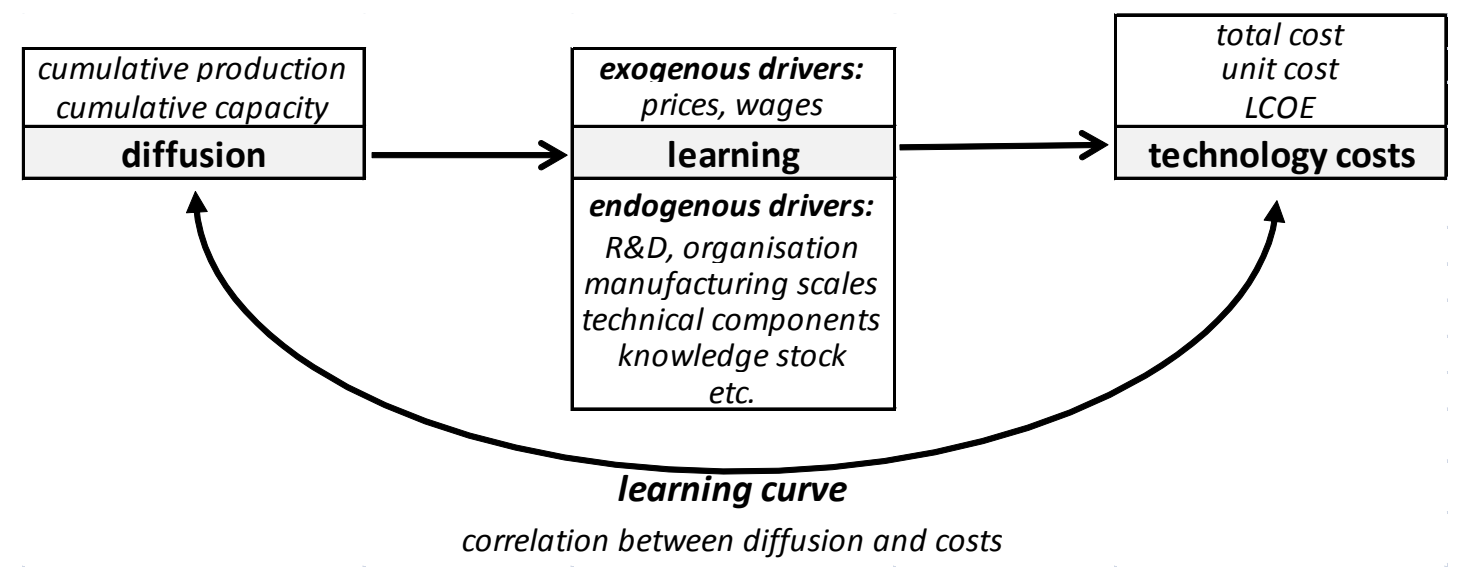

Source: Authors' composition.

In conclusion, learning curves can be used to assess the investment costs needed to reach a certain technology cost level. Since other factors can compensate or reinforce learning-by-doing effects, they need to be included. This should be done in a technology-, country- and case-specific way.

\section{Conclusions}

This literature review highlights that there are numerous motivations and requirements underlying the introduction of renewable energy policies. Starting with a brief overview of the induced innovation hypothesis, we showed that policy intervention has been an effective tool to change relative prices, thus, incentivizing innovation. The available literature on technological change in climate-friendly technologies seems to agree that market-based approaches are more effective than command-and-control measures such as introducing standards. However, it is also emphasized that various factors influence this effect, such as technology type, market structure and policy commitment and stringency.

Focusing on renewable energy technology innovation, the literature agrees that specific renewable energy policies are required in order to overcome concomitant market failures and barriers. The presence of market distortions inhibiting socially optimal investments in renewable energy innovation requires specially tailored policy intervention. We underline the fact that technology-specific policies for renewable energies are necessary complements to environmental non-technology-specific policies, such as emission trading or the introduction of carbon taxes in order to generate adequate demand in energy markets. There is still a lack of agreement here as to which technology-specific policies - renewable portfolio standards or feed-in tariffs - are more effective at inducing innovation. Additionally, we show that technology-push policies are necessary, especially in the early stages of technology 
development. Overall, we can confirm that there is a consensus in the literature that successful technological change requires a mix of market-pull and technology push policies.

With respect to methodological approaches to measuring policy efforts and technological change, we highlight the importance of different impact levels and stages within the technological change process. Additionally, we provide an overview of measures capturing policies for innovation as well as innovation output.

Finally, this paper provides a literature overview on two aspects of the effect of technological change on renewable energy technology. First, we show that there is an increasing body of evidence that environmental regulation and subsequent innovation can be advantageous for the international competitiveness of certain industries in terms of trade. Second, we shed some light on the effect that learningby-doing or searching (innovation) can have on reducing technology costs, but also point out that other factors can contribute to decreasing technology costs. 


\section{Bibliography}

ACEMOGLU, D. 2002, Directed technological change, Review of Economic Studies 69(4): 781-809.

ACEMOGLU, D., AGHION, P., BURSZTYN, L. \& HEMOUS, D. 2012, The Environment and Directed Technical Change, American Economic Review 102(1): 131-166.

AGHION, P. \& HOWITT, P. 1997, Endogenous Growth Theory, MIT Press, Cambridge, MA.

ALDY, J., KRUPNICK, A., NEWELL, R., PARRY, I. W. H. \& PIZER, W. A. 2010, Designing Climate Mitigation Policy, Journal of Economic Literature, American Economic Association 48(4): 903934.

ANTWEILER, W., COPELAND, B. R. \& TAYLOR, S. M. 2001, Is Free Trade Good for the Environment?, American Economic Review 91(4): 877-908.

ARROW, K. J. 1962, Economic welfare and the allocation of resources for invention, In: (NBER), N. B. O. E. R. (ed.) The rate and direction of inventive activity: Economic and social factors, Princeton University Press, Princeton, NJ.

ARTHUR, W. B. 1989, Competing technologies, increasing returns, and lock-in by historical events, The Economic Journal 99(394): 116-131.

BCG 1968, Perspectives of Experience, Boston Consulting Group Inc., Boston, MA.

BECK, F. \& MARINOT, E. 2004, Renewable energy policies and barriers, In: CUTLER, C. (ed.) Encyclopedia of Energy, Academic Press and Elsevier Science, San Diego.

BEISE, M. 2004, Lead Markets: Country-Specific Drivers of the Global Diffusion of Innovations, Research Policy 33(6-7): 997-1018.

BEISE, M. \& RENNINGS, K. 2005, Lead Markets and Regulation: A Framework for Analyzing the International Diffusion of Environmental Innovations, Ecological Economics 52(1): 5-17.

BENNEAR, L. S. \& STAVINS, R. N. 2007, Second-best theory and the use of multiple policy instruments, Environmental and Resource Economics 37(2007): 111-129.

BERGEK, A. \& JACOBSSON, S. 2003, The emergence of a growth industry: A comparative analysis of the German, Dutch and Swedish wind turbine industries, In: METCALFE, J. \& CANTNER, U. (eds.) Change, transformation and development, Physica Verlag, Heidelberg.

BOHI, D. \& TOMAN, M. A. 1996, Economics of Energy Security, Kluwer Academic Publishers, Norwell, M.A.

BOLINGER, M. \& WISER, R. 2012, Understanding wind turbine price trends in the U.S. over the past decade, Energy Policy 42(2012): 628-641.

BREITSCHOPF, E.M HALLER, I., GRUPP, H., 2005, Bedeutung von Innovation für Wettbewerbsfähigkeit, in: Handbuch Technologie- und Innovationsmanagement, ed. Albers, S., Gassmann, O., Betriebswirtschaftl. Verlag Dr. th. Gabler, Wiesbaden

BRAUN, F. G., SCHMIDT-EHMKE, J. \& ZLOCZYSTI, P. 2010. Innovative Activity in Wind and Solar Technology: Empirical Evidence on Knowledge Spillovers Using Patent Data. DIW Berlin Discussion Papers [Online], 993.

BROCK, W. A. \& TAYLOR, M. S. 2005, Economic Growth and the Environment: A Review of Theroy and Empirics, In: AGHION, P. \& DURLAUF, S. (eds.) Handbook of Economic Growth 1.Elsevier North Holland, Amsterdam.

BROWN, M. A. 2001, Market failures and barriers as a basis for clean energy policy, Energy Policy 29(14): 1197-1207.

BRUNNERMEIER, S. B. \& COHEN, M. A. 2003, Determinants of environmental innovation in US manufacturing industries, Journal of Environmental Economics and Management 45(2): 278293.

BÜRER, M. J. \& WÜSTENHAGEN, R. 2009, Which renewable energy policy is a venture capitalist's best friend? Empirical evidence from a survey of international cleantech investors, Energy Policy 37(12): 4997-5006. 
BUTLER, L. \& NEUHOFF, K. 2005, Comparison of Feed in Tariff, Quota and Auction Mechanisms to Support Wind Power Development, Cambridge Working Papers in Economics No. 0503, Cambridge, UK.

CLEFF, T. \& RENNINGS, K. 2011, Theoretical and Empirical Evidence of Timing-to-Market and Lead Market Strategies for Successful Environmental Innovation, Simon Fraser University Department of Economics Working Papers No. 11-01.

COENEN, L. \& DİAZ, F. 2010, Comparing systems approaches to innovation and technological change for sustainable and competitive economies:an explorative study into conceptual commonalities, differences and complementarities, Journal of Cleaner Production 18(12): $1149-1160$.

COLE, M., ELLIOT, R. \& OKUBO, T. 2010, Trade, environmental regulation and industrial mobility: an industry-level study of Japan, Ecologival Economics 69(10): 1995-2002.

COLE, M., ELLIOT, R. \& SHIMAMOTO, K. 2005, Industrial characteristics, environmental regulation and air pollution: an analysis of the UK manufacturing sector, Journal of Environmental Economics and Management 50(1): 121-143.

COPELAND, B. R. \& TAYLOR, M. S. 2003, Trade and the Environment: Theory and Evidence, Princton University Press.

COSTANTINI, V. \& CRESPI, F. 2008, Environmental Regulation and the Export Dynamics of Energy Technologies, Ecological Economics 66(2-3): 447-460.

COSTANTINI, V. \& MAZZANTI, M. 2012, On the green and innovative side of trade competetivness? The impact of environmental policies and innovation on EU exports, Research Policy 41: 132153.

COUNCIL, E. P. A. O. T. 2009, Directive 2009/28/EC of the European Parliament and of the Council of 23 April 2009 on the promotion of the use of energy from renewable sources and amending and subsequently repealing Directives 2001/77/EC and 2003/30/EC, Official Journal of the European Union 14016-62.

CRABB, J. M. \& JOHNSON, D. K. 2010, Fueling innovation: The impact of oil prices and CAFE standards on energy-efficient automotive technology, The Energy Journal 31(1): 199-216.

DEL RíO GONZÁLEZ, P. 2008, Ten years of renewable electricity policies in Spain: An analysis of successive feed-in tariff reforms, Energy Policy 36(8): 2917-2929.

DEL RÍO GONZÁLEZ, P. \& GUAL, M. A. 2007, An integrated assessment of the feed-in tariff system in Spain, Energy Policy 35(2): 994-1012.

DEL RIO, P. 2009, Interactions between climate and energy policies: the case of Spain, Climate Policy 9(2009): 119-138.

DEL RIO, P. \& BLEDA, M. 2012, Comparing the innovation effects of support schemes for renewable technologies: A function of innovation approach, Energy Policy 50(2012): 272-282.

DONG, C. G. 2012, Feed-in tariff vs. renewable portfolio standard: An empirical test of their relative effectiveness in promoting wind capacity development, Energy Policy 42(3): 476-485.

DOWLATABADI, H. 1998, Sensitivity of climate change mitigation estimates to assumptions about technical change, Energy Economics 20(5-6): 473-493.

EDENHOFER, O. \& STERN, N. 2009, Towards a global green recovery, Graham Research institute on Climate Change and the Environment and Postdam Institute of for Climate Impact Research on behalf of the German Foreign Office, Berlin.

EDQUIST, C. 2006, Systems of Innovation: Perspectives and Challenges, In: FAGERBERG, J., MOWERY, D. \& NELSON, R. (eds.) The Oxford Handbook of Innovation, Oxford University Press, Oxford.

EGENHOFER, C., ALESSI, M., GEORGIEV, A. \& FUJIWARA, N. 2011, The EU Emissions Trading System and Climate Policy towards 2050: Real incentives to reduce emissions and drive innovation? , CEPS Special Report.

EGENHOFER, C., GIALOGU, K., LUCIANI, G., BOOTS, M., SCHEEPERS, M., CONSTANTINI, V., GRACCEVA, F., MARKANDYA, A. \& VICINI, G. 2004, Market-based options for Security in Energy Supply, Fondazione Eni Enrico Matei, Nota Di Lavoro 117. 
FERIOLI, F., SCHOOTS, K. \& VAN DER ZWAAN, B. C. C. 2009, Use and limitations of learning curves for energy technology policy: A component-learning hypothesis, Energy Policy 37(2009): 25252535.

FINON, D. \& MENANTEAU, P. 2008, The static and dynamic efficiency of instruments of promotion of renewables, Energy Studies Review 22(1): 53-83.

FISCHER, A. C. 2005, Technical innovation and design choices for emissions trading and other climate policies, In: HNSJÜRGENS, B. (ed.) Emissions Trading for Climate Policy - US and European Perspectives, Cambridge University Press, Cambridge.

FISCHER, C. 2008, Emissions pricing, spillovers, and public investment in environmentally friendly technologies, Energy Economics 30(2): 487-502.

FISCHER, C. \& NEWELL, R. G. 2008, Environmental and technology policies for climate mitigation, Journal of Environmental Economics and Management 55(2): 142-162.

FISCHER, C., PARRY, I. W. H. \& PIZER, W. A. 2003, Instrument choice for enviromental protection when technological innovation is endogenous, Journal of Environmental Economics and Management 45(3): 523-545.

FOXON, T. J., GROSS, R., CHASE, A., HOWES, J., ARNALL, A. \& ANDERSON, D. 2005, UK innovation systems for new and renewable energy technologies: drivers, barriers and systems failures, Energy Policy 33(16): 2123-2137.

FOXON, T. J. \& PEARSON, P. J. G. 2007, Towards improved policy processes for promoting innovatin in renewable electricity technologies in the UK, Energy Policy 35(2007): 1539-1550.

FRI, R. W. 2003, The role of knowledge: technological innovation in energy systems, The Energy Journal 24(4): 51-74.

GAGELMANN, F. \& FRONDEL, M. 2005, The Impact of Emission Trading on Innovation - Science Fiction or Reality, European Environment 15(4): 203-211.

GALEOTTI, M. \& KEMFERT, C. 2004, Interactions between Climate and Trade Policies: A Survey, Journal of World Trade 38(4): 701-724.

GERLAGH, R., KVERNDOKK, S. \& ROSENDAHL, K. 2009, Optimal timing of climate change policy: Interaction between carbon taxes and innovation externalities, Environmental and Resource Economics 43(3): 369-390.

GILLINGHAM, K. \& SWEENEY, J. 2010, Market Failures and the Structure of Externalities, In: PADILLA, A. J. \& SCHMALENSEE, R. (eds.) Harnessing Renewable Energy,

GRAY, W. B. \& SHADBEGIAN, R. J. 1998, Environmental Regulation, Investment Timing, and Technology Choice, Journal of Industrial Economics 46(2): 235-256.

GREEN, W. H. 2002, Econometric Analysis, New Jersey.

GRETHER, J.-M. \& DE MELO, J. 2003. Globalization and Dirty Industires: Do Pollution Havens Matter?, NBER Working Papers [Online].

GRILICHES, Z. 1990, Patents as Economic Indicators: A Survey, Journal of Economic Literature 28(4): 1661-1707.

GROBA, F., INDVIK, J. \& JENNER, S. 2013, Assessing the Strength and Effectiveness of Renewable Electricity Feed-in-Tariffs in European Union Countries, Energy Policy 52: 385-401.

GRUBB, M. 2004, Technology innovation and climate change policy: an overview of issues and options, Keio Economic Studies 41(2): 103-132.

GRUBB, M., HADUONG, M. \& CHAPUIS, T. 1995, The economics of changing course, Energy Policy 23(4/5): 417-432.

GRUBB, M., KOEHLER, J. \& ANDERSON, D. 2002, Induced technical change in energy/environmental modelling: analytic approaches and policy implications, Annual Review of Energy and the Environment 27(1): 271-308.

GRUBLER, A. 2010, The costs of the French nuclear scale-up: a case of negative learning by doing, Energy Policy 38/39(2010): 5174-5188.

GRUBLER, A., NAKICENOVIC, N. \& VICTOR, D. G. 1999, Dynamics of energy technologies and global change, Energy Policy 27(5): 247-280. 
HAAS, R., EICHHAMMER, W., HUBER, C., LANGNISS, O., LORENZONI, A., MADLENER, R., MENANTEAU, P., MORTHORST, P. E., MARTINS, A., ONISZK, A., SCHLEICH, J., SMITH, A., VASS, Z. \& VERBRUGGEN, A. 2004, How to promote renewable energy systems successfully and effectively, Energy Policy 32(6): 833-839.

HAAS, R., MEYER, N. I., HELD, A., FINON, D., LORENZONI, A., WISER, R. \& NISHIO, K.-I. 2008, Promoting Electricity from Renewable Energy Sources - Lessons Learned from the EU, United States, and Japan, In: SIOSHANSI, F. P. (ed.) Competitive Electricity Markets, Elsevier, Oxford.

HAAS, R., RAGWITZ, M., RESCH, G., PANZER, C., BUSCH, S. \& HELD, A. 2011, Efficiency and effectiveness of promotion systems for electricity generation from renewable energy sources - Lessons from EU countries, Energy 36: 2186-2193.

HAHN, R. W. \& STAVINS, R. N. 1991, Incentive-based environmental regulation: A new era from an old idea?, Ecology Law Quaterly 18(1): 1-42.

HAMAMOTO, M. 2006, Environmental regulation and the productivity of Japanese manufacturing industries, Resource and Energy Economics 28(1): 299-312.

HARRIS, M. N., KONYA, L. \& MATYAS, L. 2002, Modelling the Impact of Environmental Regulations on Bilateral Trade Flows: OECD, 1990-1996, World Economy 25(3): 387-405.

HASCIC, I., JOHNSTONE, N., POIRIER, J., HEMAR, M. \& MICHEL, C. 2012, Environmental Policy Stringency and Technological Innovation: Evidence from Survey Data and Patent Counts, Applied Economics 44(17): 2157-2170.

HASSET, K. A. \& METCALF, G. E. 1993, Energy conservation investment: do consumers discout the future correctly, Energy Policy 21: 710-716.

HASSET, K. A. \& METCALF, G. E. 1995, Energy tax credits and residential conservation investments: Evidence from panel data, Journal of Public Economics 57(1): 201-217.

HEKKERT, M. P., HARMSEN, R. \& DEJONG, A. 2007, Explaining the rapid diffusion of Dutch cogeneration by innovation system functioning, Energy Policy 35(9): 4677-4687.

HENRIQUES, I. \& SARDORSKY, P. 2008, Oil prices and the stock pieces of alternative energy companies, Energy Economics 30(3): 998-1010.

HERNANDEZ-MORO, J. \& MARTINEZ-DUART, J. M. 2013, Analytical model for solar PV and CSP electricity costs: Present LCOE values and their future evolution, Energy Reviews 20(2013): 119-132.

HICKS, J. 1932, The Therory of Wages, Macmillan, London.

HOFFERT, M. 2002, Advanced technology paths to climate stability: energy for a greenhouse planet, Science 298(1): 981-987.

HOFFMANN, V. H. 2007, EU ETS and Investment Decisions: The Case of the Germanc Electricity Industry, European Management Journal 25(6): 464-474.

HUGHES, T. 1986, he Seamless Web: Technology, Science, Etcetera, Etcetera, Social Studies of Science 16(2): 281-292.

IPCC 2007, Climate Change 2007: Synthesis Report, WMO and UNEP, Geneva.

IPCC 2011, IPCC Special Report on Renewable Energy Sources and Climate Change Mitigation, Working Group III of the Intergovernmental Panel on Climate Change, Cambridge and New York.

ISOARD, S. \& SORIA, A. 2001, Technical change dynamics: evidence from the emerging renewable energy technologies, Energy Economics 23(2001): 629-639.

JAFFE, A. B. 1986, Technological Opportunity and Spillovers of R\&D: Evidence from Firms Patents, Profits, and Market Value, The American Economic Review 76(5): 984 - 1001.

JAFFE, A. B., NEWELL, R. \& STAVINS, R. N. 2002, Environmental Policy and Technological Change, Environmental and Resource Economics 22: 41-69.

JAFFE, A. B., NEWELL, R. \& STAVINS, R. N. 2004, The Economics of Energy Efficiency, In: CLEVELAND, C. (ed.) Encyclopedia of Energy, Elsevier, Amsterdam. 
JAFFE, A. B., NEWELL, R. G. \& STAVINS, R. N. 2003, Technological change and the environment, In: MÄLER, K.-G. \& VINCENT, J. R. (eds.) Handbook of Environmental Economics, 1.ed., Elsevier, Amsterdam.

JAFFE, A. B., NEWELL, R. G. \& STAVINS, R. N. 2005, A tale of two market failures: Technology and environmental policy, Ecological Economics 54(2-3): 164-174.

JAFFE, A. B. \& PALMER, K. 1997, Environmental Regulation and Innovation: A Panel Data Study, The Review of Economics and Statistics 79(4): 610-619.

JAFFE, A. B., PETERSON, S., PORTNEY, P. \& STAVINS, R. N. 1995, Environmental regulation and the competetivness of US manufacturing. What does the evidence tell us?, Journal of Economic Literature 33: 132-163.

JAFFE, A. B. \& STAVINS, R. N. 1994, The energy-efficiency gap, Energy Policy 22(10): 804-810.

JAFFE, A. B. \& STAVINS, R. N. 1995, Dynamic Incentives of Environmental Regulations: The Effects of Alternative Policy Instruments on Technology Diffusion, Journal of Environmental Economics and Management 29(3): 43-63.

JAMASB, T. \& POLLITT, M. 2008, Liberalisation and R\&D in network industries: The case of the electricity industry, Research Policy 37(6-7): 995-1008.

JARREAU, J. \& PONCET, S. 2012, Export sophistication and economic growth: Evidence from China, Journal of Development Economics 97(2): 281-292.

JOHNSTONE, N. \& HAŠČIČ, I. 2009. Environmental Policy Design and the Fragmentation of International Markets for Innovation. CESifo Working Paper Series [Online].

JOHNSTONE, N., HAŠČIČ, I. \& POPP, D. 2010, Renewable Energy Policies and Technological Innovation: Evidence Based on Patent Counts, Environmental and Resource Economics 45(1): 133-155.

JUG, J. \& MIRZA, D. 2005, Environmental Regulation in Gravity Equations: Evidence from Europe, World Economics 28(11): 1591 - 1615.

JUNGINGER, M., DE VISSERA, E., HJORT-GREGERSEN, K., KOORNNEEF, J., RAVEN, R., FAAIJA, A. \& TURKENBURGA, W. 2006, Technoloical learing in bioenergy systems, Energy Policy 34(2006): 4024-4041.

KATZ, M. L. \& SHAPIRO, C. 1985, Network externalities, competition, and compatibility, The American Economic Review 75(3): 424-440.

KEMP, R. 1997, Environmental policy and technical change: a comparison of the technological impact of policy instruments, Edward Elgar Publishing, Cheltenham.

KEMP, R., SCHOT, J. \& HOOGMA, R. 1998, Regime shifts to sustainability through processes of niche information: the approach of strategic niche management, Technology Analysis and Strategic Management 10(1): 175-195.

KERR, S. \& NEWELL, R. G. 2003, Policy-induced technology adoption: Evidence from the U.S. lead phasedown, Journal of Industrial Economics 51(3): 317-343.

KLAASSEN, G., MIKETA, A., LARSEN, K. \& SUNDQVIST, T. 2005, The impact on R\&D on innovation for wind energy in Denmark, Germany and the United Kingsom, Ecological Economics 54(1): 227240.

KLEIN, A., HELD, A., RAGWITZ, M., RESCH, G. \& FABER, T. 2008. Evaluation of Different Feed-in Tariff Design Options: Best Practice Paper for the International Feed-in Cooperation.

KOBOS, P. H., ERICKSON, J. D. \& DRENNEN, T. E. 2006, Technological learning and renewable energy costs: implications for US renewable energy policy, Energy Policy 34(2006): 1645-1658.

KYDD, J. DORWARD, A. 2004, Implications of market and coordination failures for rural development in least developed countries. J. Int. Dev., 16: 951-970.

LANGNISS, O. \& WISER, R. 2003, The renewable portfolio standard in Texas: an early assessment, Energy Policy 31(6): 527-535.

LANIOUW, J. O. \& MODY, A. 1996, Innovation and the international diffusion of environmentally responsive technology, Research Policy 25: $549-571$. 
LANOIE, P., LAURENT-LUCCHETTI, J., JOHNSTONE, N. \& AMBEC, S. 2011, Environmental Policy, Innovations and Performance: New Insights on the Porter Hypothesis, Journal of Economics and Management Strategy 20(3): 803-842.

LANOIE, P., PATRY, M. \& LAJEUNESSE, R. 2008, Environmental regulation and productivity: new findings on the Porter Hypothesis, Journal of Productivity Analysis 30: 121-128.

LEHMANN, P. \& GAWEL, E. 2013, Why should support schemes for renewable electricity complement the EU emissions trading scheme?, Energy Policy 52(1): 597-607.

LESSER, J. A. \& SU, X. 2008, Design of an economically efficient feed-in tariff structure for renewable energy development, Energy Policy 36(3): 981-990.

LEVINE, M. D., KOOMEY, J. G., MCMAHON, J. E., SANSTAD, A. \& HIRST, E. 1995, Energy Efficiency Policy and Market Failures, Annual Review of Energy and Environment 20: 535-555.

LEVINSON, A. \& NIEMANN, S. 2004, Energy use by appartment tenants when landlords bay for utilities, Resource and Energy Economics 26: 51-75.

LINN, J. 2008, Energy Prices and the Adoption of Energy-Saving Technology, Economic Journal, Royal Economic Society 118(533): 1986-2012.

LIPP, J., 2007.. ENERGY POLICY 35(11), 5481 - 5495. 2007, Lessons for effective renewable electricity policy from Denmark, Germany and the United Kingdom, Energy Policy 35(11): 5481-5495.

LÜTHI, S. 2010, Effective deployment of photovoltaics in the Mediterranean countries: Balancing policy risk and return, Solar Energy 84(6): 1059-1071.

MAGAT, W. A. 1978, Pollution control and technological advance: A dynamic model of the firm, Journal of Environmental Economics and Management 5(1): 1-25.

MAGAT, W. A. 1979, The effects of environmental regulation on innovation, Law and Contemporary Problems 43(1): 3-25.

MAHAPATRA, S., CHANAKYA, H. N. \& DASAPPA, S. 2009, Evaluation of various energy devices for domestic lighting in India: Technology, economics and $\mathrm{CO} 2$ emissions, Energy for Sustainable Development 13(4): 271-279.

MARINOVA, D. \& BALAGUER, A. 2009, Transformation in the photovoltaics industry in Australia, Germany and Japan: Comparison of actors, knowledge, institutions and markets, Renewable Energy 34(2): 461-464.

MARTINOT, E., WISER, R. \& HAMRIN, J. 2005. Renewable Energy Markets and Policies in the United States.

MENANTEAU, P., FINON, D. \& LAMY, M.-L. 2003, Prices versus quantities: choosing policies for promoting the development of renewable energy, Energy Policy 31(8): 799-812.

MENDONCA, M. 2007, Feed-in Tariffs - Accelerating the Development of Renewable Energy, Management of Environmental Quality: An International Journal 19(1).

MILLIMAN, S. R. \& PRINCE, R. 1989, Firm incentives to promote technological change in pollution control, Jounral of Environmental Economics and Management 17(3): 247-265.

MITCHELL, C., BAUKNECHT, D. \& CONNOR, P. 2006, Effectiveness through risk reduction: a comparison of the renewable obligation in England and Wales and the feed-in system in Germany, Energy Policy 34(3): 297-305.

MITCHELL, C., SAWIN, J. L., POKHAREL, G. R., KAMMEN, D., WANG, Z., FIFITA, S., JACCARD, M., LANGNISS, O., LUCAS, H., NADAI, A., TRUJILLO BLANCO, R., USHER, E., VERBRUGGEN, A., WÜSTENHAGEN, R. \& YAMAGUCHI, K. 2011, Policy, Financing and Implementation, In: EDENHOFER, O., PICHS-MADRUGA, R., SOKONA, Y., SEYBOTH, K., MATSCHOSS, P., KADNER, S., ZWICKEL, T., EICKEMEIER, P., HANSEN, G., SCHLÖMER, S. \& VON STECHOW, C. (eds.) IPCC Special Report on Renewable Energy Sources and Climate Change Mitigation, Cambridge University Press, Cambridge and New York.

MONTERO, J. P. 2002, Market structure and environmental innovation, Journal of Applied Economics 5(2): 293-325.

MURTISHAW, W. \& SATHAYE, J. 2006, Quantifying the effect of the principal-agent problem on US residential energy use, Lawrence Berkley National Labaroty, Berkley, C.A. 
NEGRO, S. O., HEKKERT, M. P. \& SMITS, R. E. 2007, Explaining the failure of the Dutch innovation system for biomass digestion - a function alanalysis, Energy Policy 35(2): 925-938.

NEIJ, L. 1997, Use of experience curves to analyse the prospects for diffusion and adoption of renewable energy technologies, Energy Policy 23(13): 1099-1107.

NEMET, G. F. 2006, Beyond the learning curve: factors influencing cost reductions in photovoltaics, Energy Policy 34(17): 3218-3232.

NEUHOFF, K. 2005, Large-Scale Deployment of Renewables for Electricity Generation, Oxford Review of Economic Policy 21(1): 88-110.

NEUHOFF, K. 2008, Learning by Doing with Constrained Growth Rates: An Application to Energy Technology Policy, The Energy Journal 29(Special Issues 2): 165-82.

NEWELL, R. G., JAFFE, A. B. \& STAVINS, R. N. 1999, The induced innovation hypothesis and energysaving technological change, Quarterly Journal of Economics 114(1): 941-975.

NILL, J. \& KEMP, R. 2009, Evoluntionary Approaches for sustainable innovation policies: from niche to paradigm?, Research Policy 38(2009): 668-680.

NORDHAUS, W. 2002, Modeling induced innovation in Climate Change Policy, In: GRUBLER, A., NAKICENOVI, N. \& NORDHAUS, W. (eds.) Technological Change and the Environment, Resources for the Future Press, Washington D.C.

OECD 2009, Eco-innovation in Industry: Enabling Green Growth, Paris.

OECD 2010, Taxation, Innovation and the Environment, OECD Green Growth Studies, OECD Publishing, Paris.

OECD 2011, Towards Green Growth, Paris.

OWEN, A. D. 2006, Renewable energy: Ecternality costs as market barrier, Energy Policy 34(5): 632642.

PAINULY, J. P. 2001, Barriers to renewable energy penetration; a framework for analysis, Renewable Energy 24(19): 74-89.

PANZER, C. H. 2012, Investment costs of renewable electricity technologies - the impact of learning effects and volatile energy and raw material prices, Südwestdeutscher Verlag für Hochschulschriften, Saarbrücken.

PETERS, M., SCHNEIDER, M., GRIESSHABER, T. \& HOFFMANN, V. H. 2012, The impact of technologypush and demand-pull policies on technical change - Does the locus of policies matter?, Research Policy 41(8): 1296-1308.

PIZER, W. A., HARRINGTON, W., KOPP, R. J., MORGENSTERN, R. D. \& SHIH, J.-S. 2002, Technology Adoption and Aggregate Energy Efficiency, Resources for the Future Discussion Paper No.0252.

POPP, D. 2002, Induced Innovatzion and Energy Prices, The American Economic Review 92(1): 160180.

POPP, D. 2003, Polution control innovations and the Clean Air Act of 19990, Journal of Policy Analysis and Mangement 22(1): 641-660.

POPP, D. 2006, ENTICE-BR: The effects of backstop technology R\&D on climate policy models, Energy Economics 28(2): 188-222.

POPP, D., HASCIC, I. \& MEDHI, N. 2011, Technology and the diffusion of renewable energy, Energy Economomics 33: 648-662.

POPP, D., NEWELL, R. G. \& JAFFE, A. B. 2010, Energy, The Environment, and Technological Change, In: HALL, B. H. \& ROSENBERG, N. (eds.) Handbook of the Economics of Innovation. Vol.2.

PORTER, M. E. \& VAN DER LINDE, C. 1995, Toward a New Conception of the EnvironmentCompetetivness Relationship, Journal of Economic Perspectives 9(4): 97-118.

RAGWITZ, M., HELD, A., RESCH, G., FABER, T., HUBER, C. \& HAAS, R. 2005, Final Report: Monitoring and Evaluation of Policy Instruments to Support Renewable Electricity in EU Member States, Fraunhofer Institute Systems and Innovation Research and Energy Economics Group, Karlsruhe, Germany and Vienna, Austria. 
RAGWITZ, M., SCHADE, W., BREITSCHOPF, B., WALZ, R., HELFRICH, N., RATHMANN, M., RESCH, G., PANZER, C., FABER, T., HAAS, R., NATHANI, C., HOLZHEY, M., KONSTANTINAVIVIUTE, I., ZAGAME, P., FOUGEYOROLLAS, A. \& LE HIR, B. 2006, EmployRES - The impact of renewable energy policy on economic growth and employment in the European Union, Final report research project conducted on behalf of the European Commission, DG Energy and Transport, European Commission, Karlsruhe, Brussels.

ROGGE, K. S. \& HOFFMANN, V. H. 2010, The impact of the EU ETS on the sectoral innovation system for power generation technologies - Findings for Germany, Energy Policy 38(12): 7639-7652.

ROGGE, K. S., SCHNEIDER, M. \& HOFFMANN, V. H. 2011, The innovation impact of the EU Emission Trading System - Finding of Company case studies in the German power sector, Ecological Economics 70(2011): 513-523.

ROMER, P. M. 1990, Endogenous technological change, The Journal of Political Economy 98(5): 71102.

ROSE, N. \& JOSKOW, P. 1990, The Diffusion of New Technology: Evidence from the Electric Utility Industry, RAND Journal of Economics 21(1): 354-373.

ROSENDAHL, K. E. 2004, Cost-effective environmental policy: implications of induced technological change, Journal of Environmental Economics and Management 48(3): 1099-1121.

SANSTAD, A. H., BLUMENSTEIN, C. \& STOFT, S. E. 1995, How high are option values in energy efficiency investments, Energy Policy 23(9): 739-743.

SAWIN, J. 2004. National policy instruments: policy lessons for the advancement and diffusion of renewable energy technologies around the world. Thematic background paper. In: Proceedings of the International Conference for Renewables, Bonn.

SCHERER, F., HARHOFF, D. \& KUKIES, J. 2000, Uncertainty in the size distribution of rewards from technological innovation, Jounral of Evolutionary Economics 10(1): 175-200.

SCHMIDT, T. S., SCHNEIDER, M., ROGGE, K. S., SCHUETZ, M. J. A. \& HOFFMANN, V. H. 2012, The effects of climate policy on the rate and direction of innovation: A survey of the EU ETS and the electricity sector, Environmental Innovation and Societal Transitions 2(2012): 23-48.

SCHUMPETER, J. 1934, The theory of economic development: An inquiry into profits, capital, credit, interest, and the business cycle, Harvard University Press, Cambridge, Cambridge, MA.

SIJM, J. 2005, The interaction between the EU emission trading scheme and national energy policy schemes, Climate Policy 5(2005): 79-96.

SNYDER, L. D., MILLER, N. H. \& STAVINS, R. N. 2003, The effects of environmental regulation on diffusion: the case of chlorine manufacturing, American Economic Review 93(2): 2003.

SÖDERHOLM, P. \& SUNDQVIST, T. 2007, Empirical challenges in the use of learning curves for assessing the economic prospects of renewable energy technologies, Renewable Energy 32(2007): 2559-2578.

SOLOW, R. M. 1957, Technical change and the aggregate production function, The Review of Economics and Statistics 39(3): 312-320.

STERN, N. (ed.) 2007. The Economics of Climate Change: The Stern Review, Cambridge: Cambridge University Press.

STIGLITZ, J. E. 1999, Knowledge as a global public good, In: KAUL, I., GRUNDBERG, I. \& STERN, M. A. (eds.) Global Public Good - International Cooperation in the 21st Century, Oxford University Press, Oxford and New York.

TAYLOR, M. 2008, Cap-and-Trade Programs and Innovation for Climate Safety, University of California Working Paper.

TAYLOR, M. R., RUBIN, E. S. \& HOUNSHELL, D. H. 2003, Effect of government actions on technological innovation for SO2 control, Environmental Science and Technology 37(1): 4527-4534.

TAYLOR, M. S., RUBIN, E. \& HOUNSHELL, D. 2005, Control of SO2 emissions from power plants: a case od induced technological innovation in the US, Technological Forecasting and Social Change 72(1): 697-718. 
TOKE, D. \& LAUBER, V. 2007, Anglo-Saxon and German approaches to neoliberalism and environmental policy: The case of financing renewable energy, Geoforum 38(4): 677-687.

UNEP 2008, Public Finance Mechanisms to Mobilize Investment in Climate Change Mitigation: An overview of mechanisms being used today to help scalee up the climate mitigation markets, with a particular focus on the clean energy sector, United Nations Environment Programme (UNEP), Paris, France.

VALENTIN, S. V. 2011, Energy Symbiosis: Renewable energy and energy security, Renewable and Sustainable Energy Reviews 15(9): 4572-4578.

VAN BEERS, C. \& CAN DEN BERGH, J. C. J. M. 1997, An Empirical Multi-country Analysis of the Impact of Environmental Regulations on Foreign Trade Flows, Kyklos 50(1): 29-46.

VAN BEERS, C. \& VAN DEN BERGH, J. C. J. M. 2003, Environmental regulation impacts on international trade: aggregate and sectoral analysis with a bilateral trade flow model, International Journal of Global Environmental Issues 3(1): 14-29.

VAN DEN BERGH, J. C. J. M. \& BRUINSMA, F. R. 2008, Managing the Transition to Renewable Energy: Theory and Practice from Local, Regional and Macro Perspectives, Edward Elgar Publishing Limited, Cheltenham, UK.

VAN DEN BERGH, J. C. J. M., FERRER-I-CARBONELL, A. \& MUNDA, G. 2000, Alternative models of individual behaviour and implications for environmental policy, Ecological Economics 32(1): 43-61.

VAN DER ZWAAN, B., RIVERA-TINOCO, R., LENSINK, S. \& VAN DEN OOSTERKAMP, P. 2012, Cost reductions for offshore wind power: Exploring the balance between scaling, learning and R\&D, Renewable Energy 41(2012): 389-393.

VOLLEBERGH, H. 2007, Diffential Impact of Environmental Policy Instruments on Technological Change: A Review of the Empirical Literature, Tinbergen Institute Discussion Paper TI No. 07$042 / 3$.

VOLLEBERGH, H. \& KEMFERT, C. 2005, The Role of Technological Change for a Sustainable Development, Ecological Economics 54(2-3): 133-147.

WATANABE, C., WAKABAYASHI, K. \& MIYAZAWA, T. 2000, Industrial dynamism and the creation of a virtuous cycle between R\&D, market growth and price reduction - the case of photovoltaic power generation (PV) development in Japan, Technovation 20(1): 299-312.

WEISS, M., JUNGINGER, M., PATEL, M. K. \& BLIK, K. 2010, A review of experience curve analysis for energy demand technologies, Technological Forecasting and Social Change 77(2010): 411428.

WEITZMAN, M. L. 1974, Prices vs. Quantities, The Review of Economic Studies 41(4): 477-491.

WIGLEY, T., RICHELS, R. \& EDMONDS, C. 1996, Economic and environmental choices in the stabilization of atmospheric CO2 concentrations, Nature 379(1996): 240-243.

WILSON, C. 2012, Up-Scaling, formative phases, and learning in the historical diffusion of energy technologies, Energy Policy 50(2012): 81-94.

WHITE, W., LUNNAN, A., NYBAKK, E., KULISIC, B. 2013, The role of governments in renewable energy: The importance of policy consistency, Biomass and Bioenergy 1-9.

YEH, S. \& RUBIN, E. S. 2012, A review of uncertainties in technology experience curves, Energy Economics 34(3): 762-771.

YIN, H. \& POWERS, N. 2010, Do state renewable portfolio standards promote in-state renewable generation?, Energy Policy 38(2): 1140-1149.

YOUNG, P. 2010, Innovation and Diffusion in Heterogeneous Populations: Contagion, Social Influence and Social Learning, The American Economic Review 99(5): 1899-1924. 